\title{
17. CONSOLIDATION CHARACTERISTICS OF WEDDELL SEA SEDIMENTS: RESULTS OF ODP LEG 1131
}

\author{
William R. Bryant ${ }^{2}$ and Frank R. Rack ${ }^{2}$
}

\begin{abstract}
Examination of the geotechnical characteristics of Weddell Sea, Maud Rise, and South Orkney microcontinental margin sediments recovered during ODP Leg 113 reveals that the reduction in porosity (consolidation) of the siliciclastic, calcareous, and diatomaceous sediments is primarily a process governed by vertical stresses created by overburden. The initial porosity of the sediments in these areas is governed by the amount of diatoms present. The more diatoms, the higher the porosity.

Surficial diatom-rich sediments are everywhere overconsolidated. This is attributed to the strong microfabric created by the diatoms, calcareous and clay particles. The deeper diatom-free sediments of Maud Rise range from slightly underconsolidated to normally consolidated.

The silty clays and clays of the Weddell Sea and South Orkney margin are underconsolidated. The degree of underconsolidation of these sediments is similar to that determined in a number of different locations throughout the world's oceans. The very low permeability of the Weddell Sea and South Orkney margin sediments appears to account for this underconsolidation.
\end{abstract}

\section{INTRODUCTION}

Consolidation is the result of all processes that cause the progressive transformation of an argillaceous sediment from a clay to a shale (Skempton, 1970). The processes include (1) interparticle bonding; (2) desiccation; (3) cementation; (4) thermal expansion; (5) osmosis; and (6) the expulsion of pore water under the increasing weight of overburden. The effect of each process on consolidation will vary through time and with the physical (pressure and temperature) and chemical environment.

The surficial siliciclastic and calcareous sediments in the Weddell Sea region, recovered during Leg 113, react mainly to the effects of increasing overburden pressure. At depth, calcareous sediments are more susceptible to chemical diagenetic alterations, which may reduce porosity more than overburden pressure. In general the major reduction in porosity at shallow depth results from the expulsion of pore water by overburden pressure.

Little is known about consolidation characteristics of diatomaceous oozes, or the effects of diatoms on the physical behavior of siliciclastic and calcareous sediments. Pittenger et al. (1989) alludes to the influence of biogenic silica on geotechnical characteristics of high-latitude sediments recovered on the Vøring Plateau in the Norwegian Sea during the Ocean Drilling Program (ODP) Leg 104. Their studies suggest that vertical and lateral changes in geotechnical properties are associated with changes in composition of sediments, in particular with the biogenic silica content. High initial void ratios of sediments and low degrees of consolidation are associated with high biogenic silica content.

The presence of diatomaceous material in siliciclastic and calcareous sediments creates a material both geometrically and chemically different from clay and calcareous biogenic sediment. Diatoms are basically disc- or rod-shaped particles which are susceptible to drastic mechanical and chemical alteration, compared with the stable structural and chemical nature of illite,

\footnotetext{
${ }^{1}$ Barker, P. F., Kennett, J. P., et al., 1990. Proc. ODP, Sci. Results, 113: College Station, TX (Ocean Drilling Program).

2 Department of Oceanography, Texas A\&M University, College Station, TX
}

chlorite, and kaolinite clay minerals, the main terrigenous constituents of Weddell Sea sediments. The hollow configuration of diatom frustules allows the development of high porosity sediment. The highest porosity sediments found in the marine environment beyond the boundary layer are diatomaceous oozes.

The purposes of this study are (1) to determine the consolidation characteristics of siliciclastic, calcareous, and diatomaceous sediments of the Weddell Sea; and (2) to determine the role of diatomaceous material on the porosity and permeability of marine sediments.

\section{METHODS OF STUDY}

\section{Consolidation Characteristics Inferred from Sediment Shear Strength}

The most direct and definitive way of determining the degree of consolidation for normally- and under-consolidated sediment is to measure in situ pore-water pressures. Only in rare cases has that been achieved at sites drilled throughout the world (De Ruiter and Richards, 1983; Dunlap and Bryant, 1978).

Conditions of consolidation may be estimated approximately by examining the relationship between shear strength and overburden stress. Skempton (1970) devised an empirical relationship between shear strength and overburden stress for normally consolidated marine sediments. This relationship is given by:

$$
\mathrm{S}_{\mathrm{u}} / \sigma_{\mathrm{o}^{\prime}}=0.11+0.0037 \mathrm{I}_{\mathrm{p}}
$$

where $\mathrm{S}_{\mathrm{u}}=$ shear strength, $\sigma_{\mathrm{o}^{\prime}}=$ effective overburden stress, and $I_{p}=$ plasticity index. Sediments yielding values of this ratio which lie between 0.20 and 0.50 are generally considered normally consolidated. Sediments with shear strength-overburden stress ratios less than 0.20 are defined as underconsolidated; those with ratios larger than 0.20 are normally consolidated; and those with ratios over 0.50 are defined as overconsolidated.

Although shear strength-overburden stress relationships only give indirect indications of the degree of sediment consolidation, they are useful because of the large number of determinations that can be made in a short time. Trends of consolidation characteristics can be generated for a given sediment section, which can then be used to determine the sampling and testing scheme for more definitive investigations. 


\section{Consolidation Characteristics Inferred from Consolidation Tests}

A standard method used to determine consolidation is to measure preconsolidation pressure by analysis of void ratio to vertical effective stress relationships using an oedometer.

One-dimensional consolidation tests were performed on Leg 113 sediments using Anteus back-pressure consolidometers. This involved incremental loading of a relatively thin, laterally confined sediment sample. Axial strain-time relationships were obtained by measuring the change in sample height during the test. A complete description of this technique can be found in Lambe and Whitman (1969). A variation of this method involves the application of sufficient back pressure to redissolve gas bubbles and completely saturate the consolidation sample. Lowe (1974) discusses the benefits of this method. A serious drawback to both of the above methods is that more than 15 days are required to complete a single test, severely limiting the number of samples that can be run in a reasonable time.

Consolidation tests are used to evaluate the sediment response to an applied load. These results provide insight into the relative degree of consolidation the sediment has experienced in situ under the imposed load of the overlying sediment column. The state of consolidation is determined using the ratio of preconsolidation stress $\left(\sigma_{c}\right)$ to the calculated present effective overburden stress $\left(\sigma_{\mathrm{o}^{\prime}}\right)$. Preconsolidation stress, defined as the maximum effective stress the sediment has experienced, is usually calculated using the graphical reconstruction technique of Casagrande (1936). Various investigations, including Cooling and Skempton (1942), Bishop et al. (1965), Schmertmann (1955), and the Marine Geotechnical Consortium (1985), have concluded that the Casagrande method is inadequate under certain circumstances to define the preconsolidation stress when applied to curves from oedometer (consolidation) tests. Recent results of a study conducted at Texas A\&M University to determine preconsolidation pressures of marine sediments indicate that the Casagrande method underestimates preconsolidation pressures by $35 \%$ or more (Trimm, 1989). Other procedures for the determination of preconsolidation pressures, based on the rebound characteristics of the sediment, have been proposed by Burmister (1951) and Schmertmann (1955). Alternative methods based on the rebound characteristics and modification of the Casagrande method have been developed at Texas A\&M University. A brief discussion of these methods follows.

Examination of numerous compression curves (determined from the loading portion of the laboratory consolidation test curve) showed that as the magnitude of the expansion index (the change in void ratio per logarithmic cycle of pressure for the rebound portion of the laboratory consolidation test curve) increases, the error in the determination of the preconsolidation stress, as determined by the Casagrande method, also increases (Trimm, 1989). Analysis of compression curves containing a hysteresis loop has been used to develop a relationship between the expansion index and the preconsolidation pressure as determined by the Casagrande method. This relationship was used to adjust the values of the preconsolidation pressure determined from the initial reload portion of the compression curve using the Casagrande method.

Another method to determine the preconsolidation pressure is based on the rebound curve characteristics and the assumption that the rebound characteristics are constant for a given sediment sample. Examination of all compression curves in this study with rebound portions substantiates this assumption. Schmertmann (1955) addressed a similar problem and demonstrated that variations are predictable. The rebound method to determine the preconsolidation pressure is as follows: a point on the constant (maximum) void ratio line during the first labora- tory loading is chosen. This point is the largest vertical effective stress along the line of constant void ratio (e) and corresponds to point B (Fig. 1). If that point appears ambiguous, a point one $\log$ cycle before the point of maximum curvature on the reload curve is used. From that point a line parallel to the rebound portion of the compression curve is extended to intersect the virgin curve. That intersection is determined to be the preconsolidation pressure.

A minimum value of the preconsolidation pressure was determined to be the intersection of the extension of the virgin curve to the horizontal extension of the reload portion of the $\mathrm{e}$ vs. $\log \sigma$ curve.

The values of preconsolidation pressures used in this chapter are the minimum values as determined by the methods described directly above and the maximum values determined by either the Casagrande method $\left(\sigma_{\mathrm{c} 1}\right)$, the modified Casagrande method $\left(\sigma_{\mathrm{cs}}\right)$, or the rebound method $\left(\sigma_{\mathrm{c} 4}\right)$.

The ratio of the preconsolidation stress to the calculated effective overburden stress yields the overconsolidation ratio $\left(\mathrm{OCR}=\sigma_{\mathrm{c}} / \sigma_{\mathrm{o}^{\prime}}\right)$. Thus, for a normally consolidated sediment where the preconsolidation stress equals or closely approximates the effective overburden stress $\left(\sigma_{\mathrm{c}}=\sigma_{\mathrm{o}}\right)$, the OCR value is one. A sediment is considered overconsolidated if it has been consolidated under a stress that exceeds the present effective overburden stress $\left(\sigma_{\mathrm{c}}>\sigma_{\mathrm{o}^{\prime}}\right)$. Sediment that has not fully consolidated under the present overburden stress is underconsolidated. For

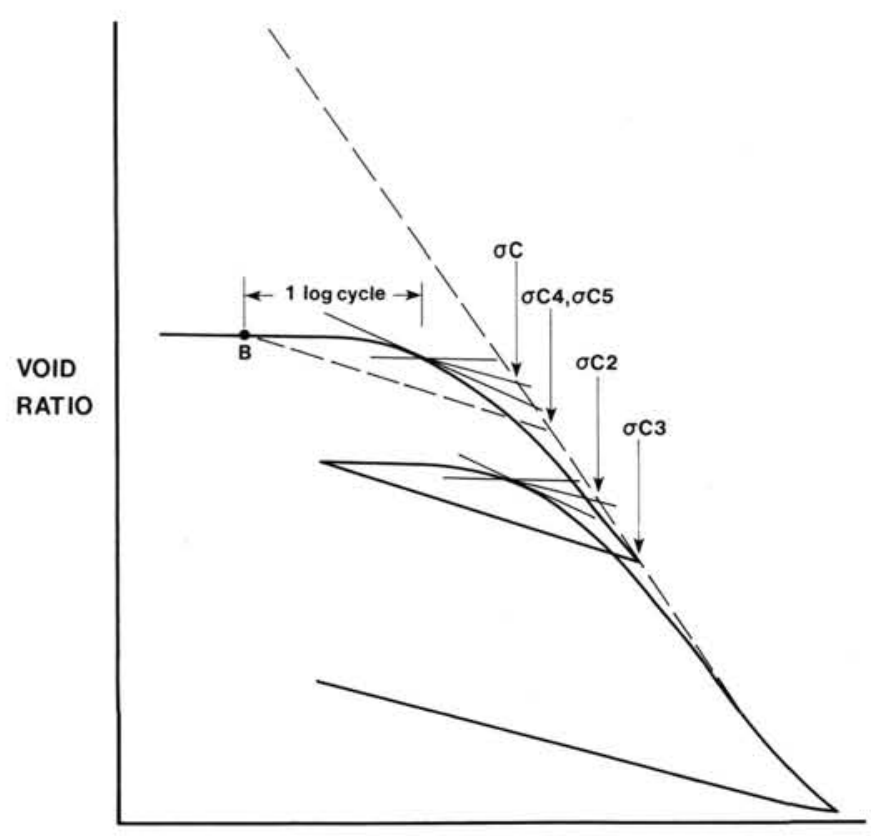

LOG EFFECTIVE STRESS

Figure 1. Hypothetical curve of void ratio (e) against log effective stress $(\log \sigma)$ showing how the calculated preconsolidation stress varies depending on the technique used (see explanation in text), $\sigma_{c}(\mathrm{~min})$ is the minimum value of preconsolidation stress. $\sigma_{\mathrm{cl}}$ is the preconsolidation stress calculated using the Casagrande (1936) technique. $\sigma_{\mathrm{c} 2}$ is the preconsolidation stress calculated using the maximum point of curvature on the reloading part of the e vs. $\log \sigma$ curve. This is significantly lower than the actual preconsolidation stress at the start of unloading, $\sigma_{\mathrm{c} 3} \cdot \sigma_{\mathrm{c} 4}$ is the preconsolidation pressure determined from rebound characteristics and the point of maximum void ratio (point B). $\sigma_{\mathrm{cs}}$ is the preconsolidation pressure determined from $\sigma_{\mathrm{c} 5}=\sigma_{\mathrm{c} 1} \times \sigma_{\mathrm{c} 3} / \sigma_{\mathrm{c} 2}$. See text for further information. 
underconsolidated sediment, the pore-water pressure exceeds the hydrostatic pressure and the preconsolidation stress will be less than the true effective overburden stress $\left(\sigma_{\mathrm{c}}<\sigma_{\mathrm{o}^{\prime}}\right)$. Essentially, excess pore pressures result in lower effective overburden stress compared to values computed assuming hydrostatic conditions. Thus, sediments with overconsolidation ratios of approximately 1.0 are considered normally consolidated, greater than 1.0 are overconsolidated, and less than 1.0 are underconsolidated.

\section{Permeability end Coefficient of Consolidation}

\section{Permeability test methods}

The movement or flux of interstitial pore water within marine deposits, which occurs during consolidation, is governed by the permeability of the sediments which, in turn, is a function of grain size, sorting, and porosity. As defined by Gray et al. (1972), permeability is "the property or capacity of a porous rock, sediment, or soil for transmitting a fluid without impairment of the structure of the medium."

There are several methods of determining permeability, in the field and in the laboratory. Permeabilities may be computed by the use of a laboratory consolidation test on the basis of the equation developed by Terzaghi (1943). This test measures the compressibility of a soil sample under a given load resulting from the escape of pore water which, in turn, is inversely related to the coefficient of permeability (k) of the sample. All permeability values presented here were computed from laboratory consolidation tests on either 6.35 or $4.45 \mathrm{~cm}$ diameter samples having initial heights of about $2.54 \mathrm{~cm}$.

The laboratory determination of permeability is usually by means of a falling (or variable-head permeameter), a constanthead permeameter, or by indirect derivation from the results of a consolidation (oedometer test) (Lambe, 1951). The time required for $90 \%$ primary consolidation $\left(t_{90}\right)$ was determined by plotting the compression dial reading against the square root of elapsed time. Tangents were drawn from the straight-line portion of the observed curve back to the zero time intersect. Through the intersect of zero time a straight line was drawn having an inverse slope equal to 1.15 times the tangent. The intersection of this line with the time-compression dial curve represents the time required to reach $90 \%$ primary consolidation. The calculation of permeability was based on Terzaghi's (1943) equation for the theory of consolidation:

$$
c_{v}=k(1+e) / g_{w} a_{v}=k / g_{w} m_{v}
$$

or

$$
\mathrm{k}=\mathrm{c}_{\mathrm{v}} \mathrm{m}_{\mathrm{v}} \mathrm{g}_{\mathrm{w}}
$$

where

$\mathrm{k}=$ coefficient of permeability $(\mathrm{cm} / \mathrm{s})$,

$c_{v}=$ coefficient of consolidation $\left(0.848 \mathrm{H}^{2} / \mathrm{t}_{90}\right)$,

$\mathrm{m}_{\mathrm{v}}=$ coefficient of volume change $\left[(\mathrm{de} / \mathrm{dp}) /(1+\mathrm{e})=\mathrm{a}_{\mathrm{v}} /\right.$ $(1+\mathrm{e})]$,

$\mathrm{a}_{\mathrm{v}}=$ coefficient of compressibility (de/dp),

$\mathrm{e}=$ void ratio (volume of voids/volume of solids),

$\mathrm{p}=$ load pressure, or stress $(\mathrm{kPa})$,

$\mathrm{H}=$ average drainage height of the sample $(\mathrm{cm})$,

$t_{90}=$ time required for $90 \%$ completion of primary consolidation,

and $\mathrm{g}_{\mathrm{w}}=$ unit weight of pore water (assumed to equal $1.05 \mathrm{~g} /$
$\mathrm{cm}^{3}$ ).
It is interesting to note that the calculated permeabilities from consolidation tests are usually one-half to one order of magnitude less than from direct measurements using the falling or variable-head technique (Marine Geotechnical Consortium, 1985).

\section{RESULTS}

\section{Site 689 (Maud Rise)}

Sediments recovered from the crest of Maud Rise, at Site 689 , consist of three lithostratigraphic units. Unit I (0-31.0 mbsf; upper Miocene to Pleistocene) consists of diatom ooze with varying amounts of other siliceous microfossils. Unit Il (31.0-149.1 mbsf; upper Eocene to upper Miocene) contains a mixture of siliceous and calcareous oozes. The calcareous component consists mainly of nannofossils. Unit III (149.1-297.3 mbsf; Campanian to upper Eocene) contains a nannofossil ooze and chalk. The dominate clay mineral present is smectite (Barker, Kennett, et al., 1988).

Figure 2 illustrates the relationship between the percentage of diatoms present, porosity, and depth below the seafloor. The direct association of porosity and diatom abundance is quite striking. An increase in diatom content corresponds to an increase in porosity. The highest porosity at Site 689 measured $91.8 \%$, which is very high for a sediment found at $5.5 \mathrm{mbsf}$. Of this sediment, $91.8 \%$ is occupied by interstices, most of which occur as voids within the diatom tests. As diatom content decreases, porosity follows. For example, between 45 and $56 \mathrm{mbsf}$, the porosity of the combined calcareous and diatomaceous sediments decreases from a value of $85 \%$ to $53 \%$. Over much the same interval the diatom content, as determined by examination of smear slides, decreases from $98 \%$ to $10 \%$. Figure 3 shows the ratio of undrained shear strength (as measured by a motorized

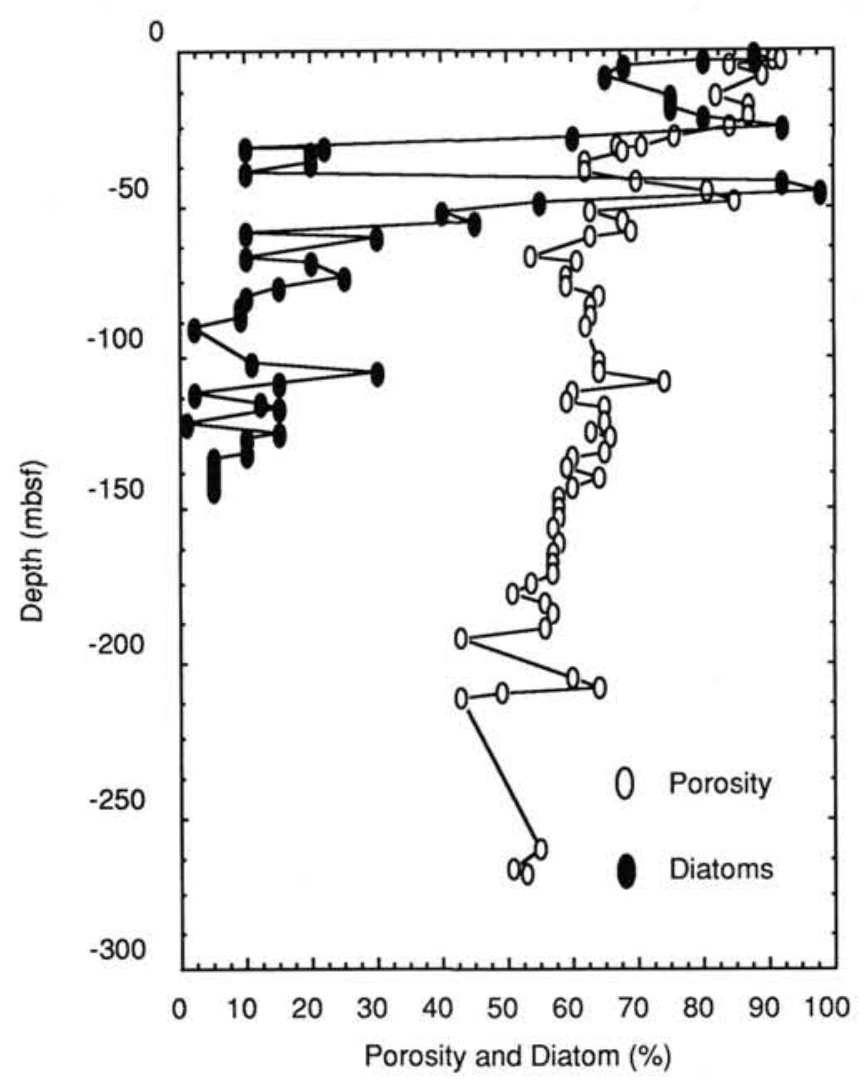

Figure 2. Profiles of porosity and percent diatoms vs. depth for Site 689. 


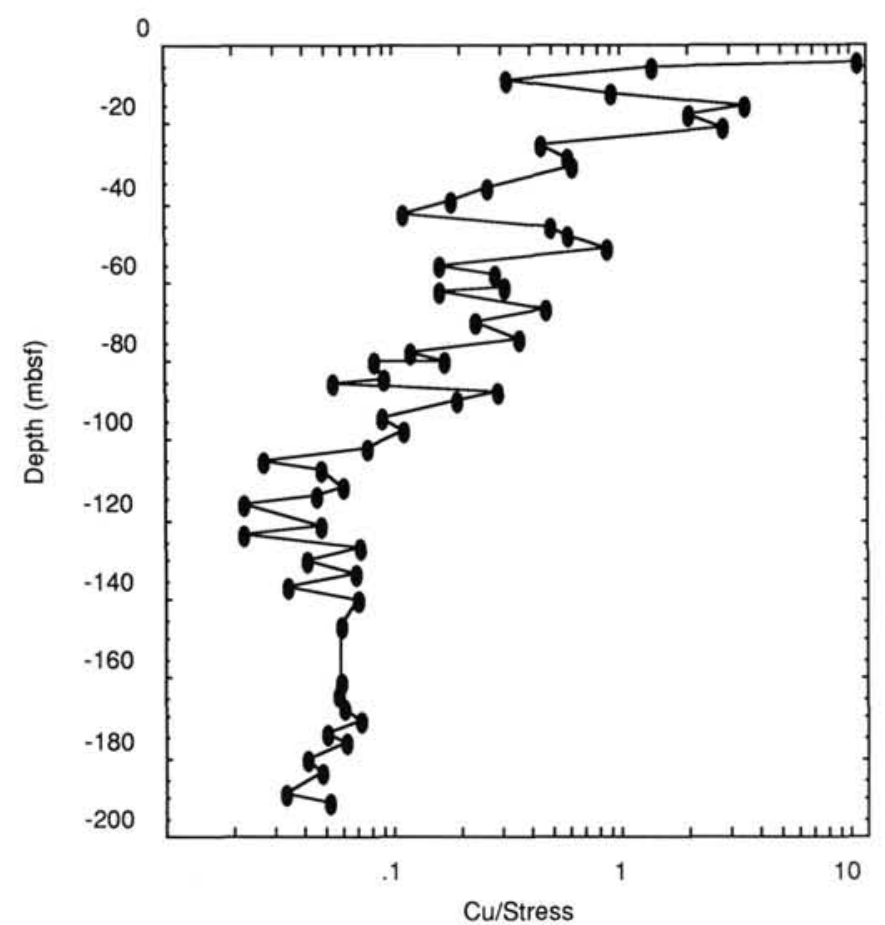

Figure 3. Ratio of undrained shear strength to vertical effective stress, plotted against depth for Hole 689D. Ratios between 0.2 and 0.5 are considered normally consolidated.

vane shear device) to vertical effective stress vs. depth downhole, for the upper $200 \mathrm{~m}$ of sediment. Most of the diatom-rich sediments above 20 mbsf are overconsolidated $\left(\mathrm{S}_{\mathrm{u}} / \sigma_{\mathrm{o}^{\prime}}\right.$ ratio $\left.>0.5\right)$. The sediments at 20-70 mbsf vary between underconsolidated and overconsolidated with the majority being normally consolidated. The calcareous sediments below 70 mbsf are all very underconsolidated. The consequence of this underconsolidation is that these sediments possess high excess pore pressures. Figure 4 illustrates the results of consolidation testing of four sediment samples recovered at $22.5,30.5,59.6$, and 115.4 mbsf. The sample recovered at 22.5 mbsf (Section 113-689C-3H-3) contains $86 \%$ diatoms. Table 1 lists the values of preconsolidation pressure determined from consolidation tests. The maximum preconsolidation pressure measured $500 \mathrm{kPa}$ and the vertical effec- tive stress $57 \mathrm{kPa}$ for the sample in Section 113-689C-3H-3. This means that the preconsolidation stress was 8.77 times the vertical stress, a highly overconsolidated condition. In all cases the diatomaceous material is overconsolidated whereas the calcareous material is normally to underconsolidated. The results of consolidation tests are similar to those derived from the ratios of undrained shear strength to vertical effective stress.

Figure 4 illustrates that the diatom-rich sediments, those at 22.5 and 30.5 mbsf, do not compress as much under high consolidation loads as other clayey marine sediments. This condition is reflected in the high porosities $(68 \%)$ ) of the sediments after being subjected to vertical stresses of $3200 \mathrm{kPa}$. Much of the porosity lies within individual diatom tests, and therefore, does not influence the flow of fluids in pore spaces between these tests.

Permeability of the diatomaceous ooze was measured at 1.9 $\times 10^{-4} \mathrm{~cm} / \mathrm{s}$, a fairly high permeability for fine-grained sedi-

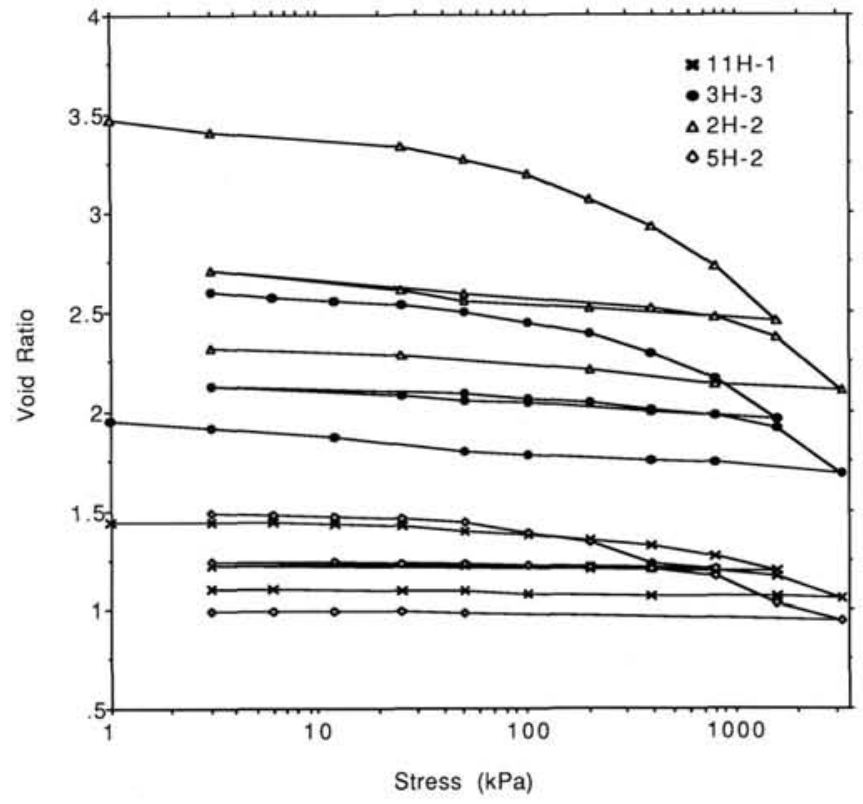

Figure 4. Curves of void ratio vs. log vertical stress for sediments from $22.5,30.5,59.6$, and $115.4 \mathrm{mbsf}$ at Hole 689D.

Table 1. Results of consolidation tests.

\begin{tabular}{|c|c|c|c|c|c|c|c|c|c|c|c|}
\hline \multirow{2}{*}{$\begin{array}{l}\text { Hole, core, } \\
\text { section }\end{array}$} & \multirow{2}{*}{$\begin{array}{l}\text { Depth } \\
\text { (mbsf) }\end{array}$} & \multirow{2}{*}{$\begin{array}{c}\text { Diatom } \\
\text { content } \\
(\%)\end{array}$} & \multirow{2}{*}{$\begin{array}{l}\text { Vertical } \\
\text { stress } \\
\text { (kPa) }\end{array}$} & \multirow{2}{*}{$\begin{array}{l}\text { Porosity } \\
(\%)\end{array}$} & \multicolumn{3}{|c|}{$\begin{array}{l}\text { Preconsolidation } \\
\text { stress }(\mathrm{kPa})\end{array}$} & \multirow{2}{*}{$\begin{array}{l}\text { Maximum } \\
\text { overconsolidation } \\
\text { ratio }\end{array}$} & \multirow{2}{*}{$\begin{array}{c}\text { Maximum } \\
\text { overconsolidation } \\
\text { difference }(\mathrm{kPa})\end{array}$} & \multirow{2}{*}{$\begin{array}{l}\text { Consolidation } \\
\text { characteristic }^{\mathrm{a}}\end{array}$} & \multirow{2}{*}{$\begin{array}{l}\text { Permeability } \\
(\mathrm{cm} / \mathrm{s} \text { at } \\
\text { vertical stress) }\end{array}$} \\
\hline & & & & & $\min$ & $\sigma_{c}^{1}$ & $\sigma_{c 4}^{1}$ & & & & \\
\hline $689 \mathrm{C}-3 \mathrm{H}-3$ & 22.5 & 86 & 57 & 72 & 300 & 400 & 500 & 8.77 & 443 & $\mathrm{HOC}$ & $1.0 \times 10^{-5}$ \\
\hline $689 \mathrm{D}-2 \mathrm{H}-2$ & 30.5 & 85 & 84 & 82 & 180 & 380 & 270 & 4.50 & 296 & HOC & $1.7 \times 10^{-5}$ \\
\hline $689 \mathrm{D}-5 \mathrm{H}-2$ & 59.6 & 20 & 217 & 67 & 200 & 245 & 230 & 1.13 & 28 & $\mathrm{NC}$ & $4.3 \times 10^{-6}$ \\
\hline $689 \mathrm{D}-11 \mathrm{H}-1$ & 115.4 & 10 & 590 & 59 & 320 & 430 & 570 & 0.96 & -20 & NC & $8.0 \times 10^{-8}$ \\
\hline $690 \mathrm{C}-2 \mathrm{H}-1$ & 7.5 & 88 & 21 & 85 & 130 & 180 & 170 & 8.57 & 149 & $\mathrm{HOC}$ & $4.7 \times 10^{-5}$ \\
\hline $690 \mathrm{C}-5 \mathrm{H}-1$ & 36.6 & 84 & 158 & 77 & 55 & 70 & 90 & 0.56 & -68 & UC & $6.7 \times 10^{-7}$ \\
\hline $690 \mathrm{C}-8 \mathrm{H}-1$ & 65.7 & 20 & 234 & 69 & 132 & 180 & 260 & 1.11 & 26 & $\mathrm{NC}$ & $2.6 \times 10^{-5}$ \\
\hline $693 \mathrm{~A}-8 \mathrm{R}-4$ & 66.28 & 22 & 437 & 63 & 47 & 70 & 80 & 0.18 & -357 & HUC & $5.8 \times 19^{-4}$ \\
\hline $695 \mathrm{~A}-4 \mathrm{H}-3$ & 24.45 & 45 & 137 & 72 & 155 & 300 & 220 & 2.19 & 163 & OC & $1.3 \times 10^{-7}$ \\
\hline $695 \mathrm{~A}-8 \mathrm{H}-3$ & 64.83 & 35 & 328 & 57 & 73 & 108 & 120 & 0.30 & -208 & UC & $3.0 \times 10^{-7}$ \\
\hline $695 \mathrm{~A}-10 \mathrm{H}-3$ & 84.05 & 42 & 441 & 67 & 135 & 235 & 200 & 0.53 & -206 & UC & $3.7 \times 10^{-9}$ \\
\hline $696 \mathrm{~A}-7 \mathrm{H}-4$ & 56.5 & 38 & 275 & 72 & 23 & 34 & 76 & 0.07 & -199 & HUC & $2.8 \times 10^{-5}$ \\
\hline 696A-9H-3 & 74.08 & 30 & 363 & 61 & 7 & 24 & 10 & 0.07 & -339 & HUC & $7.6 \times 10^{-8}$ \\
\hline $697 \mathrm{~B}-8 \mathrm{H}-3$ & 90.10 & 15 & 628 & 66 & 43 & 60 & 51 & 0.09 & -568 & HUC & $4.0 \times 10^{-6}$ \\
\hline 697B-11H-3 & 118.72 & 2 & 851 & 58 & 380 & 480 & 600 & 0.70 & -251 & UC & $2.9 \times 10^{-8}$ \\
\hline 697B-20X-3 & 200.6 & 15 & 1483 & 52 & 130 & 270 & 420 & 0.28 & -1063 & HUC & $9.0 \times 10^{-9}$ \\
\hline 697B-32X-3 & 316.66 & 0 & 2530 & 50 & 50 & 90 & 100 & 0.04 & -2430 & HUC & $1.0 \times 10^{-10}$ \\
\hline
\end{tabular}

${ }^{\text {a }} \mathrm{HOC}=$ Highly overconsolidated; $\mathrm{OC}=$ Overconsolidated; $\mathrm{NC}=$ Normally consolidated; $\mathrm{UC}=$ Underconsolidated; HUC = Highly underconsolidated. 
ment. Considering the high porosity of this ooze, the permeability is reasonable and accounts for the high degree of overconsolidation and fast drainage under low overburden pressures. The permeability of the calcareous nannofossil oozes at Site 689 is $2 \times 10^{-5}-1.4 \times 10^{-7} \mathrm{~cm} / \mathrm{s}$.

Figure 5 is the field consolidation curve derived from measured values of void ratio and the vertical effective stress calculated from bulk density measurements. The steep-sloped portion of the curve to the left of the $80 \mathrm{kPa}$ stress level represents diatom-rich sediments as does the sharp peak at $170 \mathrm{kPa}$. The fairly flat curve to the right of $170 \mathrm{kPa}$ represents mostly calcareous materials and is typical of a sediment that resists consolidation due to cementation, particle shape, and microfabric interactions.

\section{Site 690, Southwestern Flank of Maud Rise}

The lithostratigraphy of this site is similar to that of Site 689 . Unit I (0-24.4 mbsf; upper Miocene to Pleistocene) consists of diatom ooze with varying additional biosiliceous components, overlain by $2.1 \mathrm{~m}$ of foraminiferal ooze. Unit II (24.4-92.9 mbsf; lower Oligocene to upper Miocene) consists of pure and mixed siliceous and calcareous biogenic ooze. Unit III (92.9-137.8 mbsf; upper Paleocene to lower Oligocene) consists of foraminiferal nannofossil ooze. Unit IV (137.8-281.1 mbsf; upper Maestrichtian to upper Paleocene) consists of nannofossil oozes and chalk with varying amounts of terrigenous material. Units V and VI (281.1-321.2 mbsf, upper Campanian to late Maestrichtian) contain terrigenous muds, calcareous oozes and chalk, mudstones and amygdaloidal pyroxene-olivine basalt.

Figure 6 shows porosity and diatom content plotted against depth. The diatomaceous sediments have the highest porosities. The highest porosity measured at this site is $88.5 \%$ at $8.8 \mathrm{mbsf}$.

Figure 7 illustrates the relationship between the degree of consolidation, as determined by the ratio of undrained shear strength to vertical stress, and the percentage of diatoms present. Most sediments with diatom percentage above $50 \%$ are normally to overconsolidated $\left(\mathrm{S}_{\mathrm{u}} / \Sigma_{\mathrm{o}^{\prime}}>0.2\right)$, sediments with diatom contents below $10 \%$ are mostly underconsolidated $\left(\mathrm{S}_{\mathrm{u}} / \Sigma_{\mathrm{o}^{\prime}}\right.$ $<0.2$ ). Most of the calcareous sediments deeper than $50 \mathrm{mbsf}$ are underconsolidated.

Figure 8 displays the curves of void ratio vs. log vertical stress, resulting from the consolidation testing. Three samples

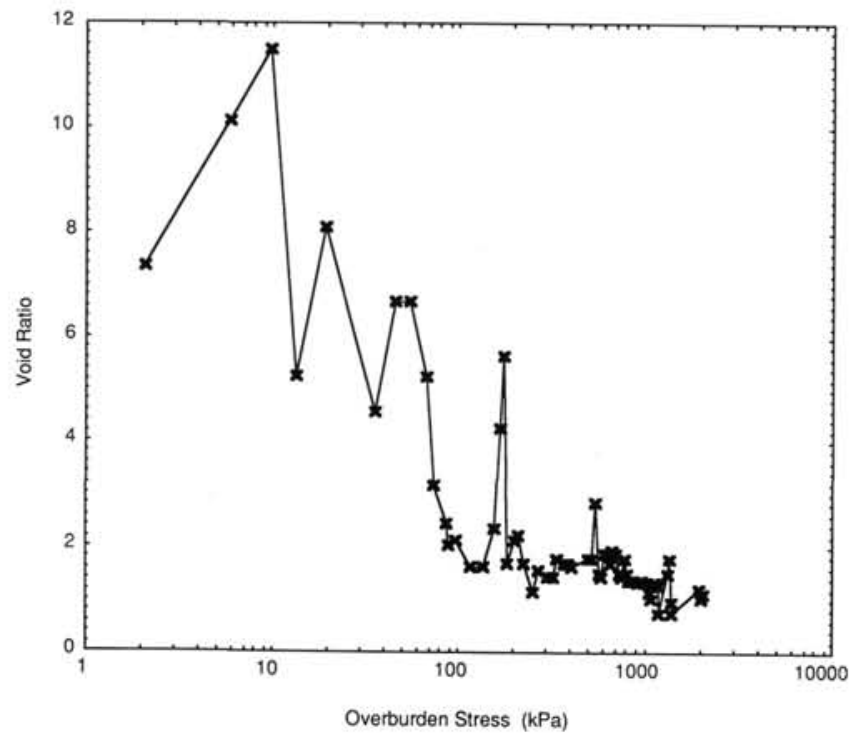

Figure 5. Field consolidation curve of sediments at Hole 689D.

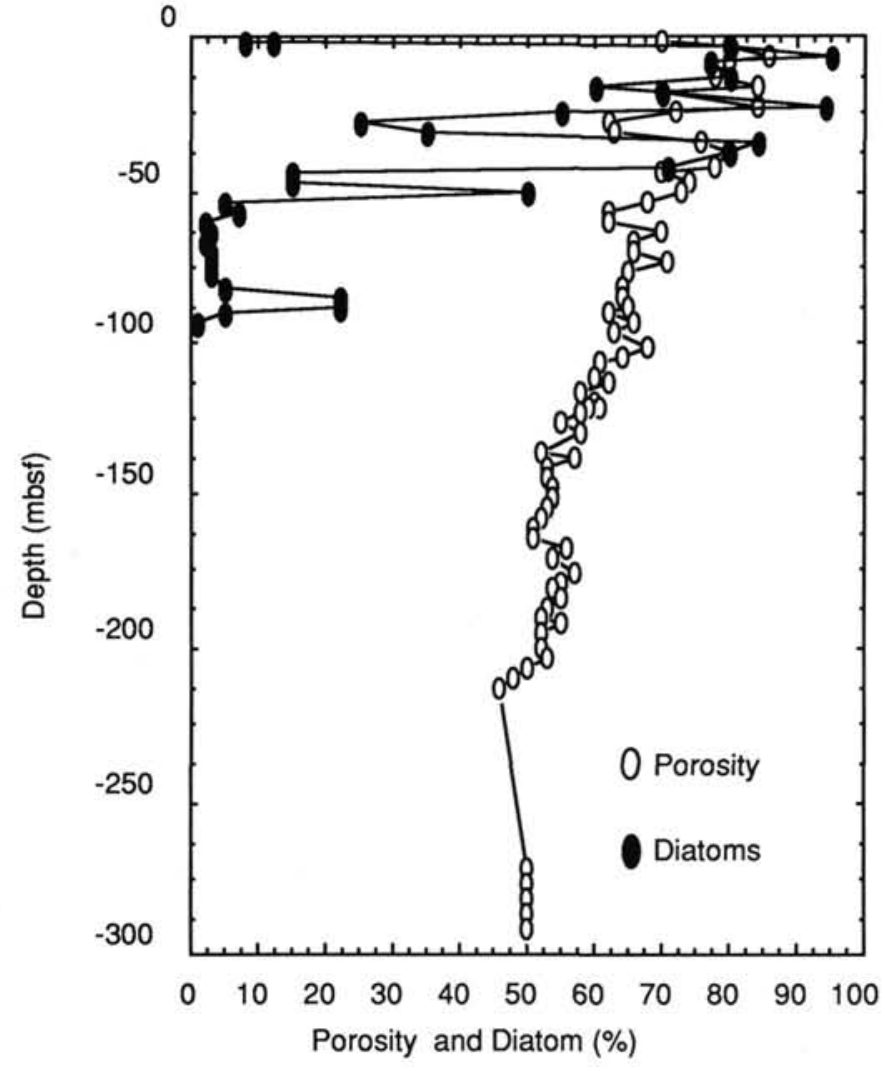

Figure 6. Profiles of porosity and percent diatoms vs. depth for Hole $690 \mathrm{C}$.

were tested, from 7.5, 36.6, and 65.7 mbsf. The consolidation data (Table 1) more or less confirm the overconsolidated nature of the diatom-rich part of the upper sediment section and the normal to underconsolidated character of the calcareous part.

Large variations in the field consolidation curve (Fig. 9), lower than the $200 \mathrm{kPa}$ level, reflect the diatomaceous nature of the material at this site. The slope of this curve to the right of the $200 \mathrm{kPa}$ level is much steeper than that determined for Site 689 sediments (see Fig. 5).

\section{Site 693}

Site 693 was located on the Dronning Maud Land margin. Seven lithostratigraphic units were identified in the $484 \mathrm{~m}$ of sediment recovered in a water depth of $2359 \mathrm{~m}$. The sediments of this site consist of $397.8 \mathrm{~m}$ of Pleistocene to lower Oligocene hemipelagic muds and $86.1 \mathrm{~m}$ of Lower Cretaceous claystone, mudstone, diatomite, and silicified sandstone.

The amount of diatomaceous material present at Site 693 and the associated porosity of the sediment is shown in Figure 10. The diatom content of the sediment, which fluctuates between $20 \%$ and $50 \%$ for most of the interval from 50 to 450 mbsf, elevates the porosity above that which one would expect for a normally consolidating, clay-rich sedimentary sequence. Figure 11 displays the ratio of undrained shear strength to vertical effective stress as a function of depth at Site 693. All of the sediment except at the shallowest measured point has a $\mathrm{S}_{\mathrm{u}} / \sigma_{\mathrm{o}}$ ratio less than 0.20 , suggesting that the whole sediment column is underconsolidated. In fact, the average $\mathrm{S}_{\mathrm{u}} / \sigma_{\mathrm{o}}$, ratio is around 0.05 , indicating a high degree of underconsolidation. The lowest ratios are generally from the intervals where the diatom content is also lowest. A consolidation test on a diatom-bearing silty clay from $66.28 \mathrm{mbsf}$ in Hole $693 \mathrm{~A}$ shows it to be highly 


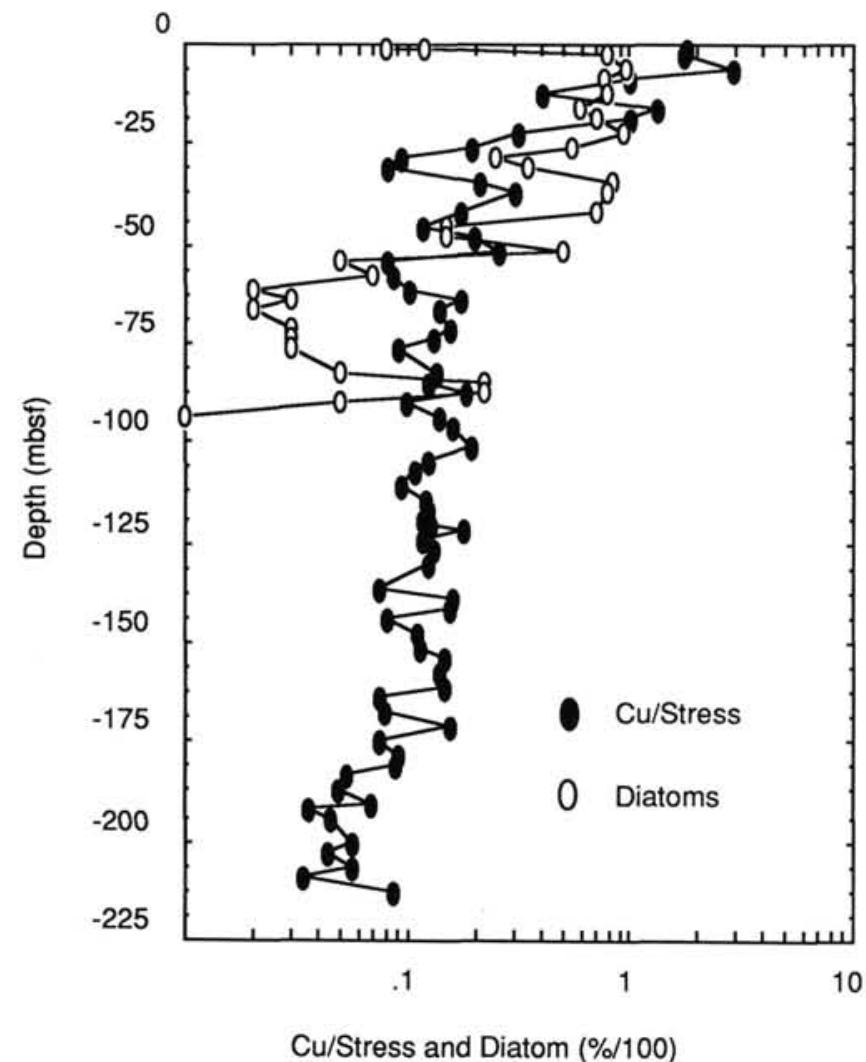

Figure 7. Ratio of undrained shear strength to vertical effective stress ratio, and the decimal percentage of diatoms present, plotted against depth for Hole $690 \mathrm{C}$. Ratios between $\mathbf{0 . 2}$ and 0.5 are considered normally consolidated.

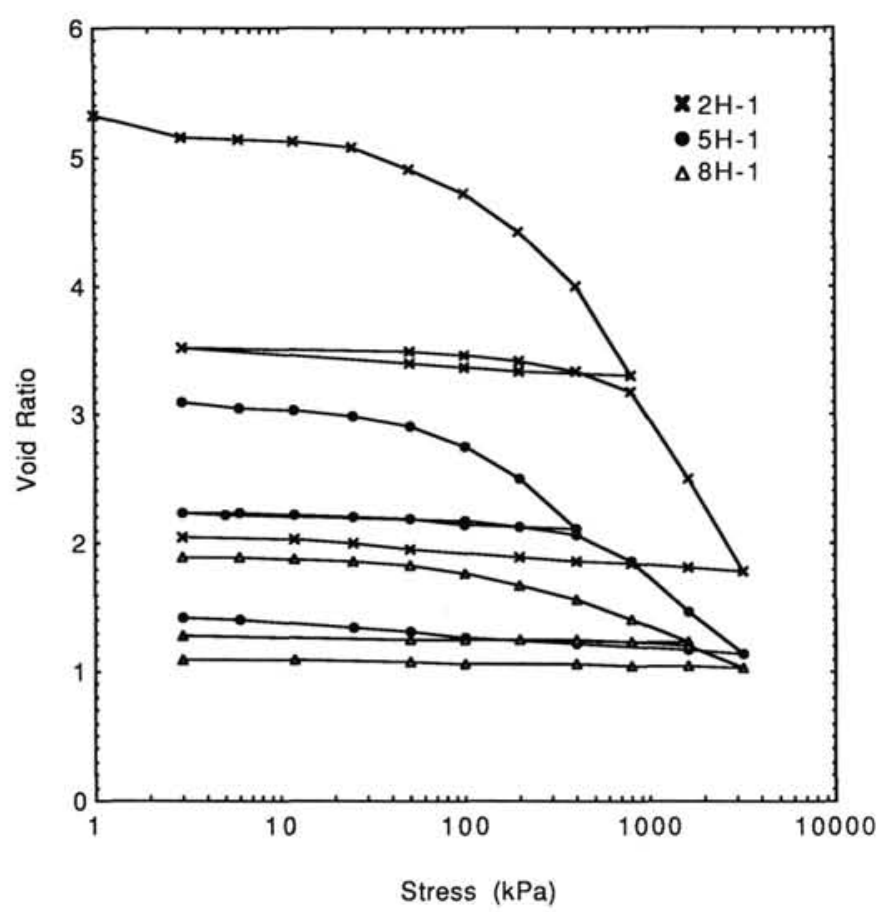

Figure 8. Curves of void ratio vs. log vertical effective stress for sediments from 7.5, 36.6, and 65.7 mbsf at Hole $690 \mathrm{C}$.

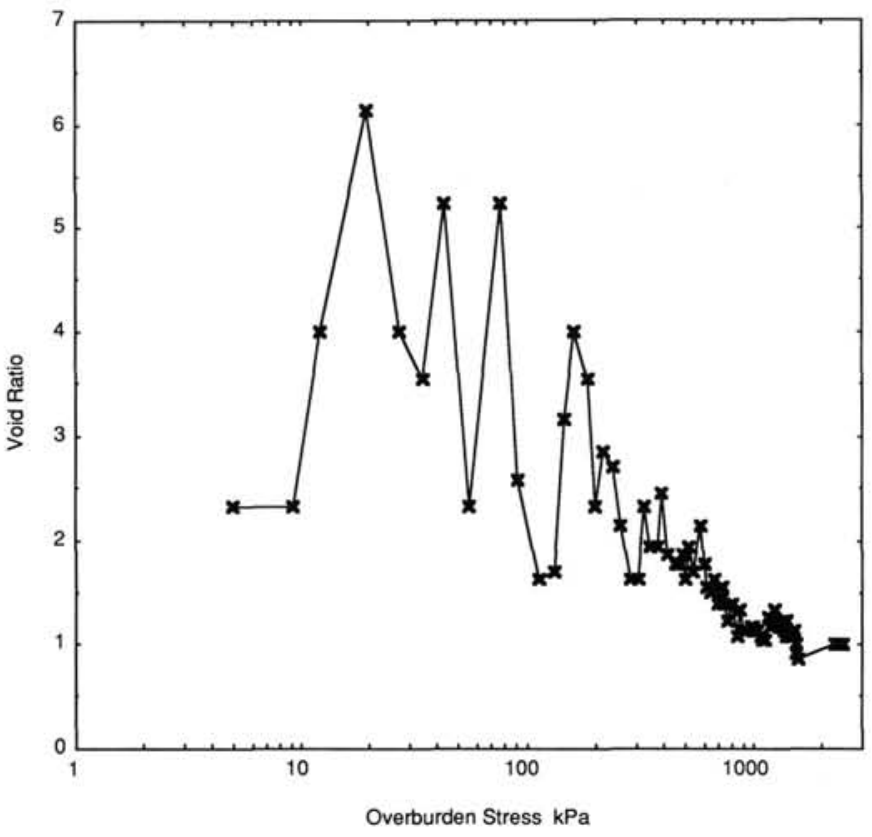

Figure 9. Field consolidation curve for Hole $690 \mathrm{C}$.

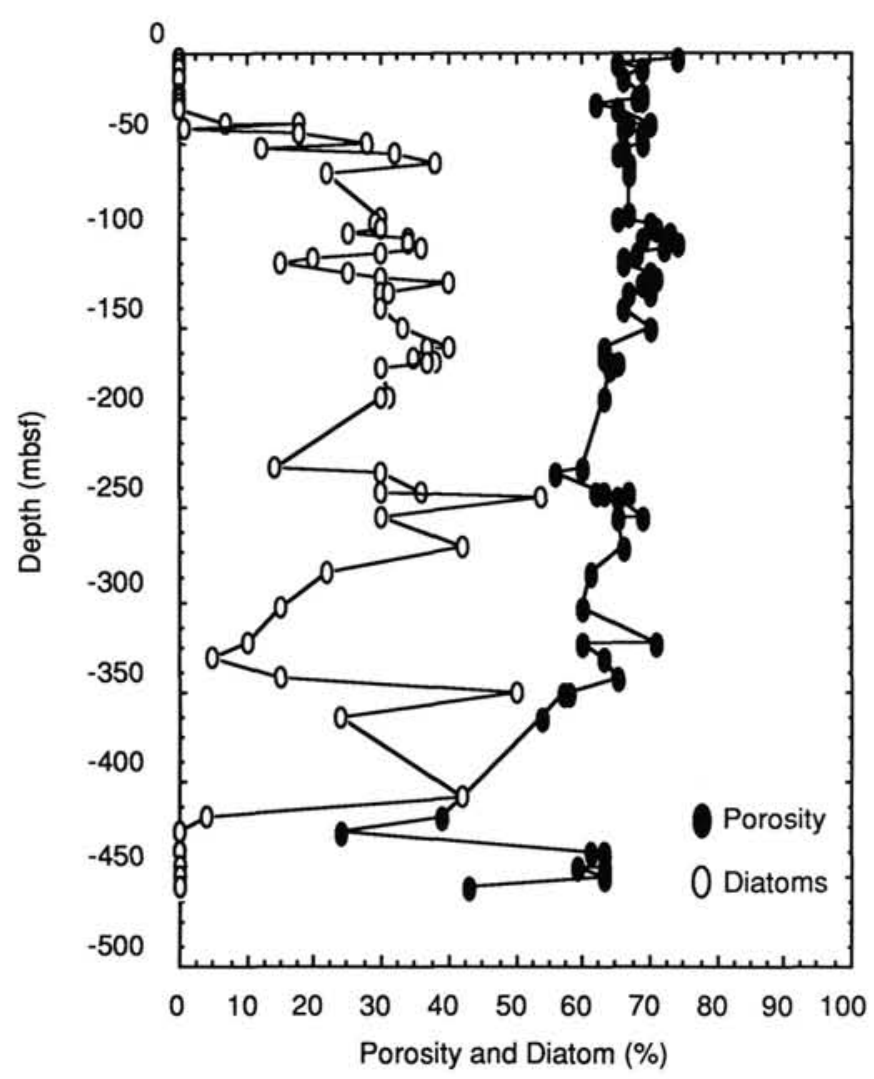

Figure 10. Profiles of porosity and percent diatoms vs. depth for Hole 693A. 


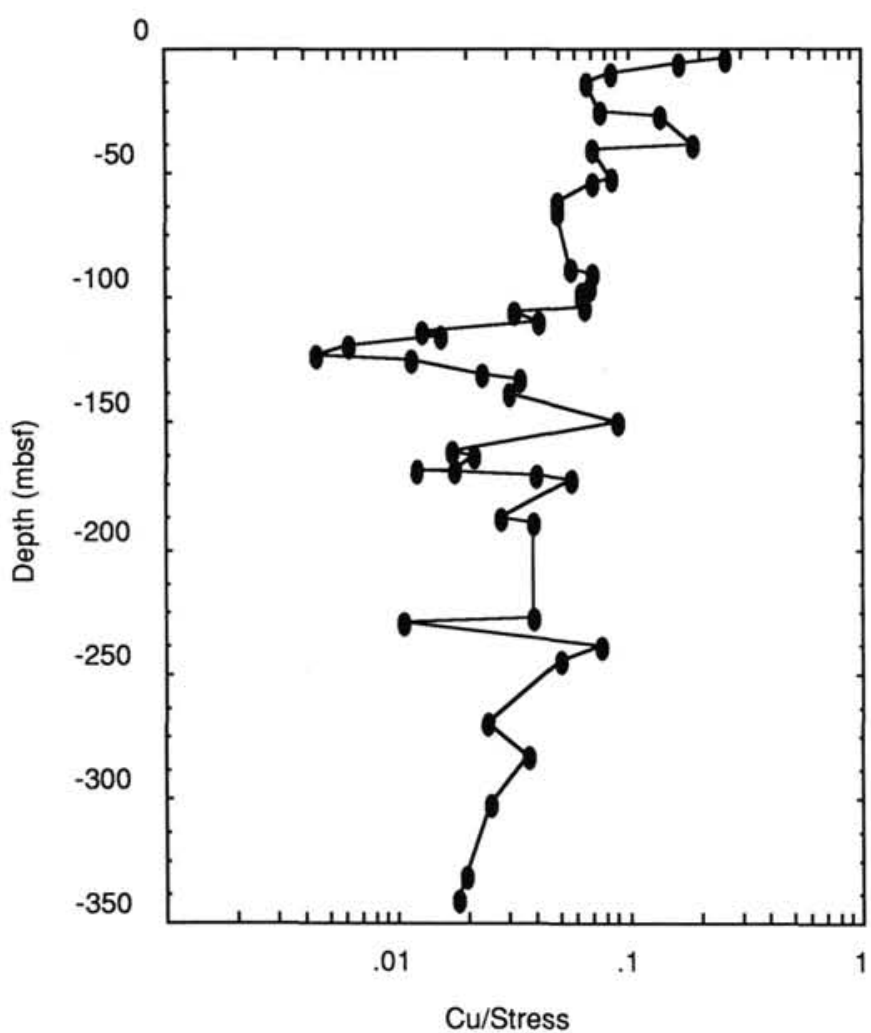

Figure 11. Ratio of undrained shear strength to vertical effective stress plotted against depth for Hole 693A. Ratios between 0.2 and 0.5 are considered normally consolidated.

underconsolidated (Table 1). The diatom content of this sample, determined from smear slides, is $22 \%$. Figure 12 , a curve of void ratio vs. log vertical effective stress for this sample, typifies the highly compressible nature of the sediments at this site.

The field consolidation curve, of void ratio vs. calculated vertical stress, is shown in Figure 13. This field consolidation

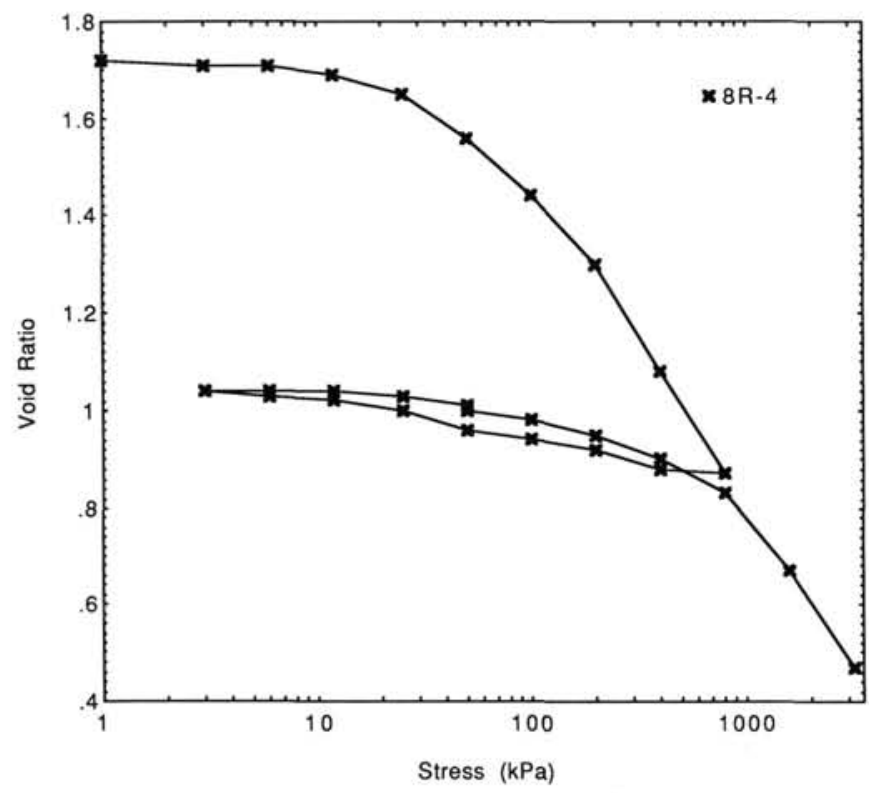

Figure 12. Curve of void ratio to log vertical stress for sediment at 66.28 mbsf in Hole 693A.

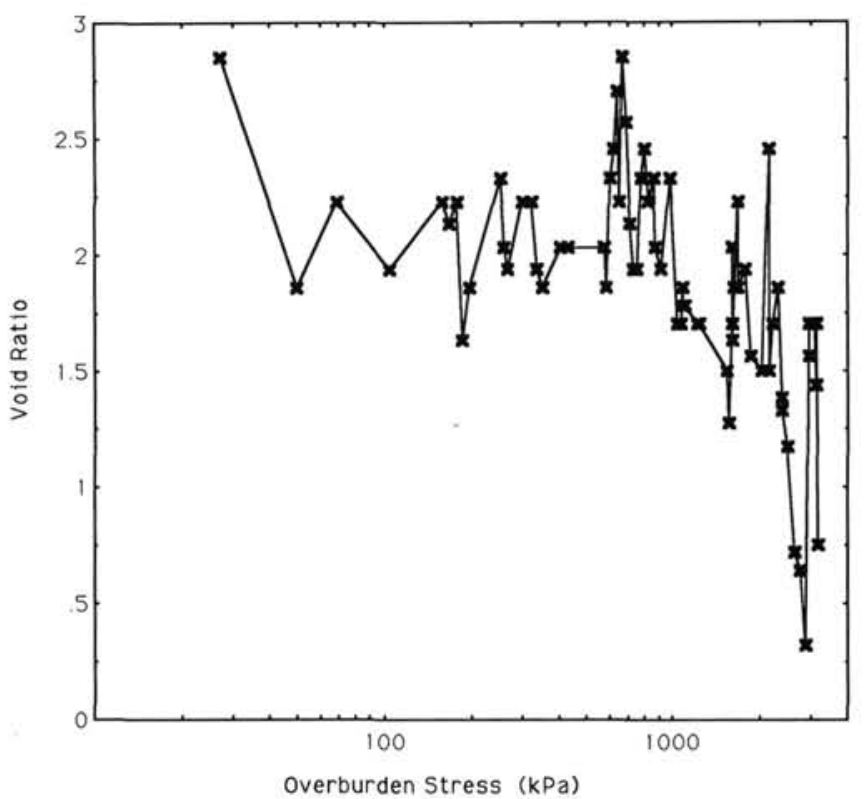

Figure 13. Field consolidation curve for Hole 693A.

curve is typical of a silty clay except for the large increases in void ratio at the $600-900 \mathrm{kPa}$ and $1000 \mathrm{kPa}$ vertical stress levels. These increases in void ratio are the direct effects of increased diatom content.

\section{Site 694}

Site 694 is located on the Weddell Abyssal Plain. The sediments sampled at this site consist of middle Miocene to Pleistocene terrigenous material with a minor biosiliceous component. Of the $391.2 \mathrm{~m}$ of sediments drilled in $4653 \mathrm{~m}$ of water almost all recovered were hemipelagic silts, clays, and turbidite sands (Barker, Kennett, et al., 1988). The porosity profile (Fig. 14) illustrates the large variation in sediment type encountered at this site. The profile includes the porosity determinations for the turbidite sands, hemipelagic silts, and clays. Even though large amounts of highly permeable sands and silts are present at Site 694 , the ratio of undrained shear strength to vertical stress of the upper 180 mbsf of sediment shows them to be apparently underconsolidated (Fig. 15). The degree of underconsolidation may reflect the disturbed condition of the sediment recovered at this site more than the natural conditions present. No consolidation tests were run on sediments from the site due to the lack of undisturbed cores.

\section{Site 695}

Site 695 is located on the margin of the South Orkney microcontinent in $1305 \mathrm{~m}$ of water. The section drilled was divided into three lithostratigraphic units by Barker, Kennett, et al. (1988). Unit I (0-190.7 mbsf; lower Pliocene to Pleistocene) contains mainly biosiliceous sediments, up to $80 \%$ diatoms. Clayey muds and silty muds are also present. Unit II (190.7-806.9 mbsf; lower Pliocene) consists of diatom-bearing silty and clayey muds. Unit III (306.9-345.1 mbsf; upper Miocene to upper Pliocene) contains silty muds with up to $10 \%$ diatoms.

Profiles of porosity and diatom content for Site 695 are shown in Figure 16. In general, high diatom content coincides with high values of porosity for this sediment. The relationship between diatom content and the value of the ratio between undrained shear strength and vertical effective stress is shown in Figure 17. The strength/stress ratio of Site 695 sediments suggests that the sediments are normally to near-normally consoli- 


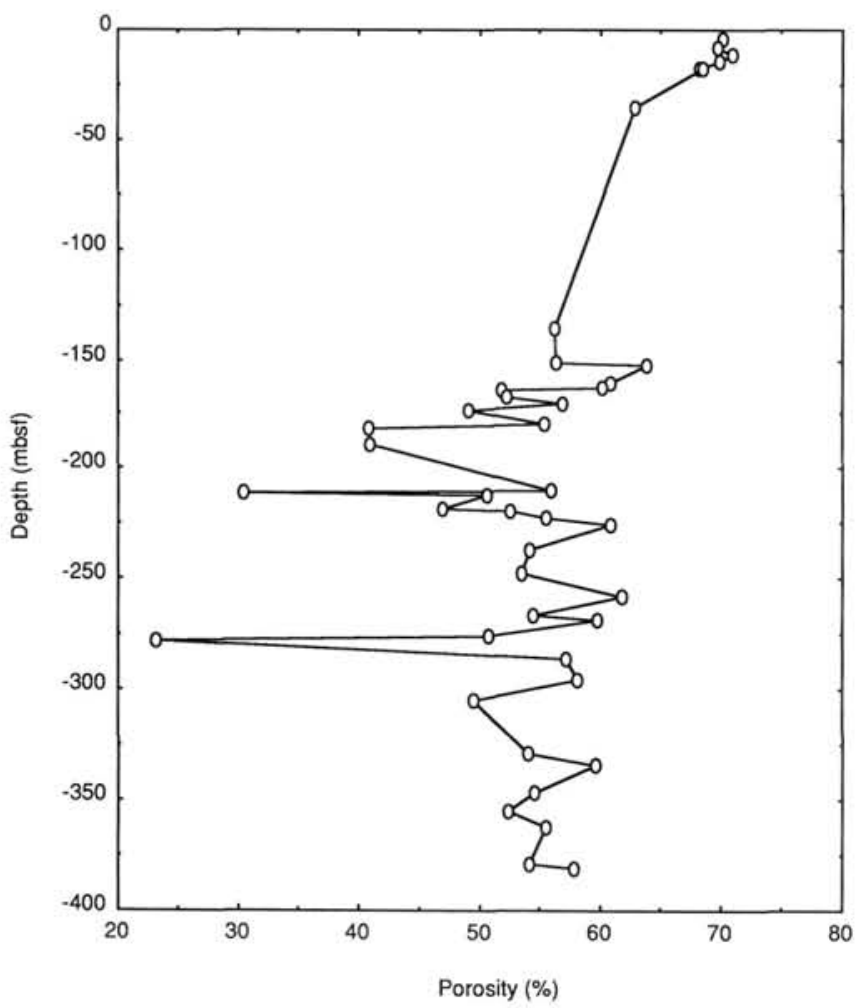

Figure 14. Porosity profile for Site 694.

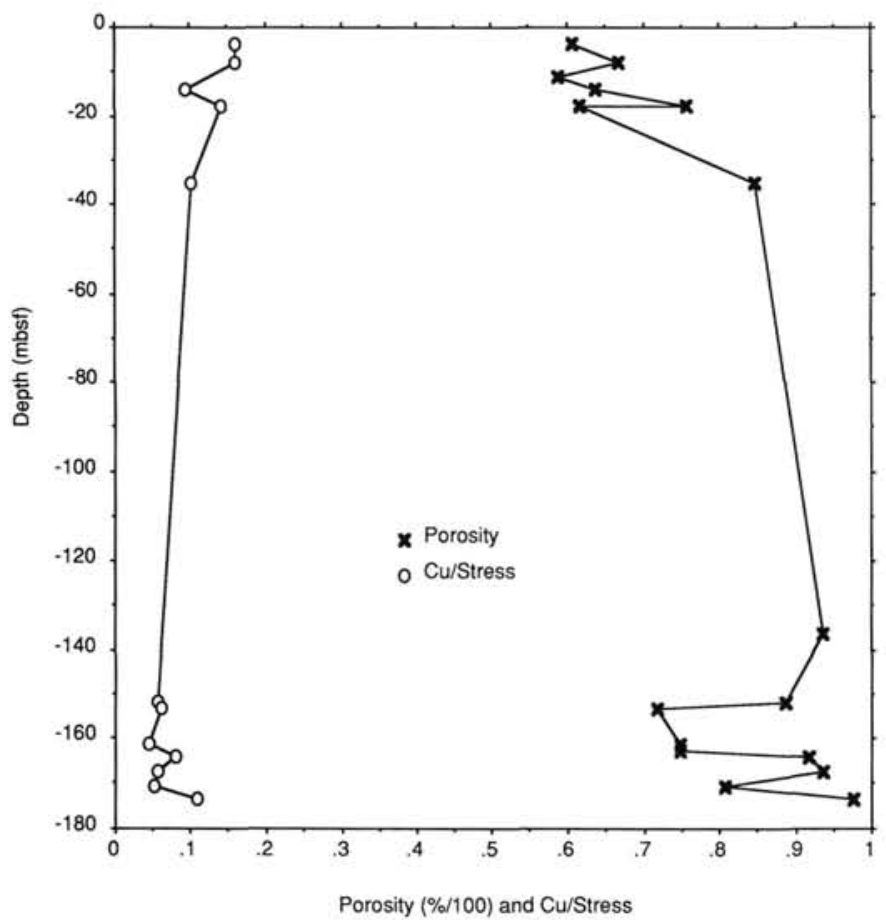

Figure 15. Ratio of undrained shear strength to vertical effective stress and porosity plotted against depth for Site 694 . Ratios between 0.2 and 0.5 are considered normally consolidated.

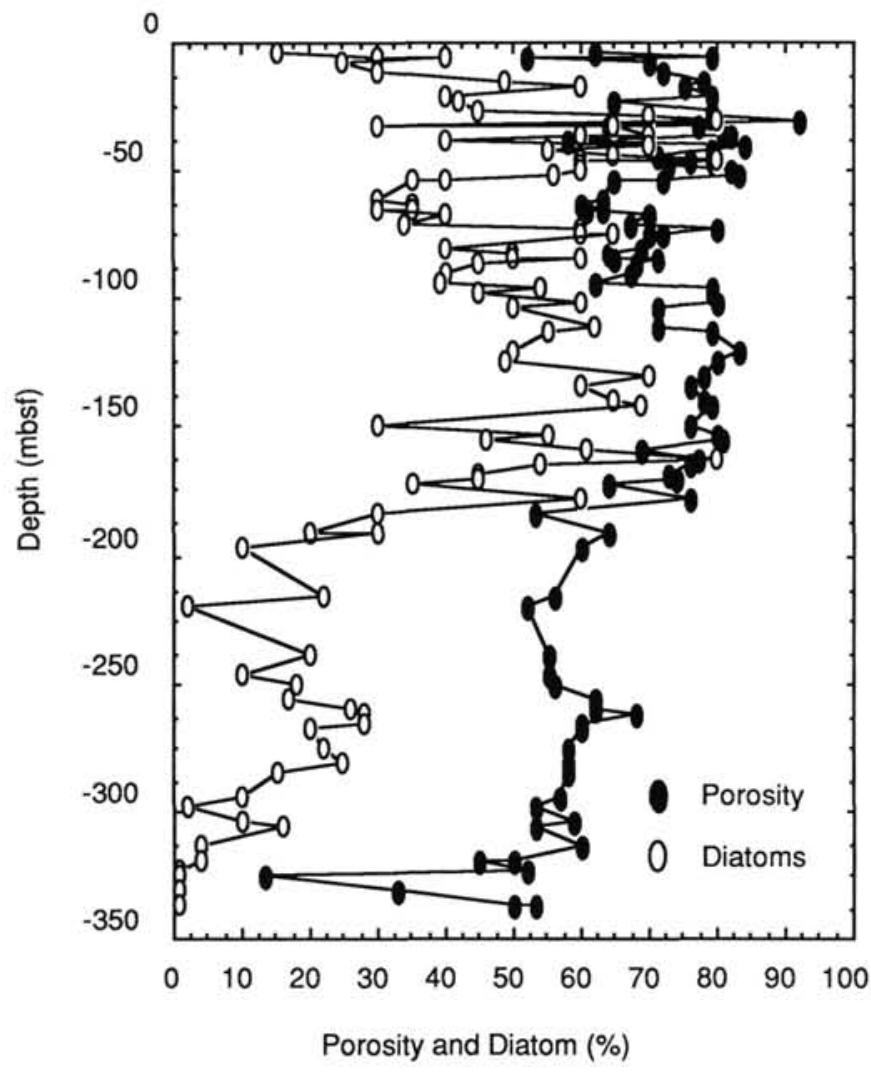

Figure 16. Profiles of porosity and percent diatoms vs. depth for Site 695A.

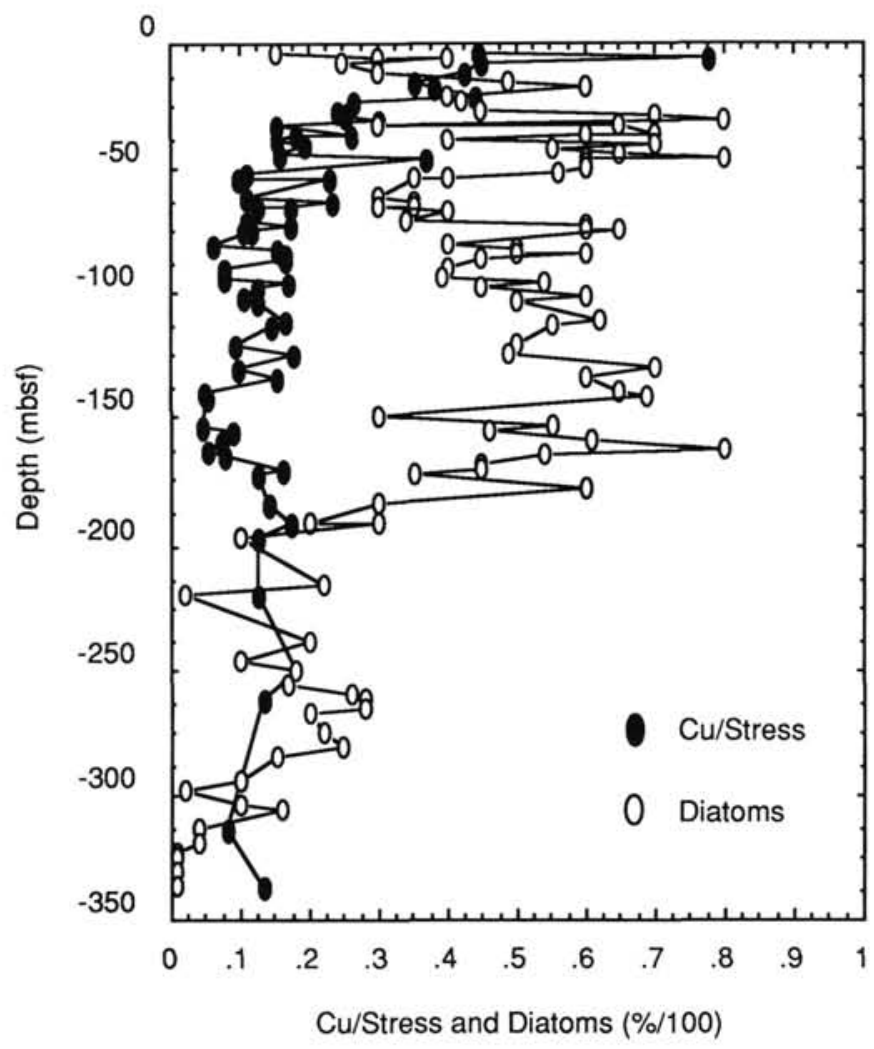

Figure 17. Ratio of undrained shear strength to vertical effective stress and decimal percent diatoms for Hole 695A, plotted against depth. 
dated $\left(\mathrm{S}_{\mathrm{u}} / \Sigma_{\mathrm{o}^{\prime}}>0.2\right)$ in the upper $50 \mathrm{~m}$ of the section, whereas sediments below $50 \mathrm{mbsf}$ are underconsolidated, some being highly underconsolidated such as those at or near $150 \mathrm{mbsf}$ where the diatom content is low.

The results of three consolidation tests on sediments from this site are summarized in Table 1 and two of the resulting void ratio vs. $\log$ effective stress are illustrated in Figure 18. Results of the consolidation tests are similar to results derived from the relationship between the shear strength and vertical effective stress, illustrated in Figure 17. The tests indicate that sediment at 26.45 mbsf is normally to slightly overconsolidated and samples from 64.88 and 84.05 mbsf are underconsolidated. The degree of underconsolidation is influenced by the amount of diatoms present. The underconsolidation of these sediments in spite of their high diatom content is attributed in part to their low permeability. The permeability at $84.05 \mathrm{mbsf}$ is $3.74 \times 10^{-9}$ $\mathrm{cm} / \mathrm{s}$. Sediment of this permeability is effectively impermeable (although over extremely long time periods, in the geological framework, some migration of fluids could occur). It is interesting to note that sediments with high diatom content may have high void ratios and porosity, but low permeabilities, as is the case at this site. A high proportion of the porosity is intra-skeletal, and therefore, not involved in the transmission of fluids.

The field consolidation curve, for Hole 695A (Fig. 19), is highly erratic and reflects the changing diatom content of the sediment at this site.

\section{Site 696}

Site 696 is located in $650 \mathrm{~m}$ of water on the southeast margin of the South Orkney microcontinent. The sedimentary section cored at this site was divided into seven lithostratigraphic units based on the relative abundance of biosiliceous, terrigenous, and authigenic components and the degree of diagenetic maturity (Barker, Kennett, et al., 1988). The $645.6 \mathrm{~m}$ of sediment drilled at Hole 696A ranges in age from Pleistocene to Eocene. Of all properties measured, the most significant difference in the upper $530 \mathrm{~m}$ of unlithified sediments is the amount of diatomaceous material present (Fig. 20). The association of diatoms and porosity shown in Figure 20 is striking, high diatom content being reflected in high porosity.

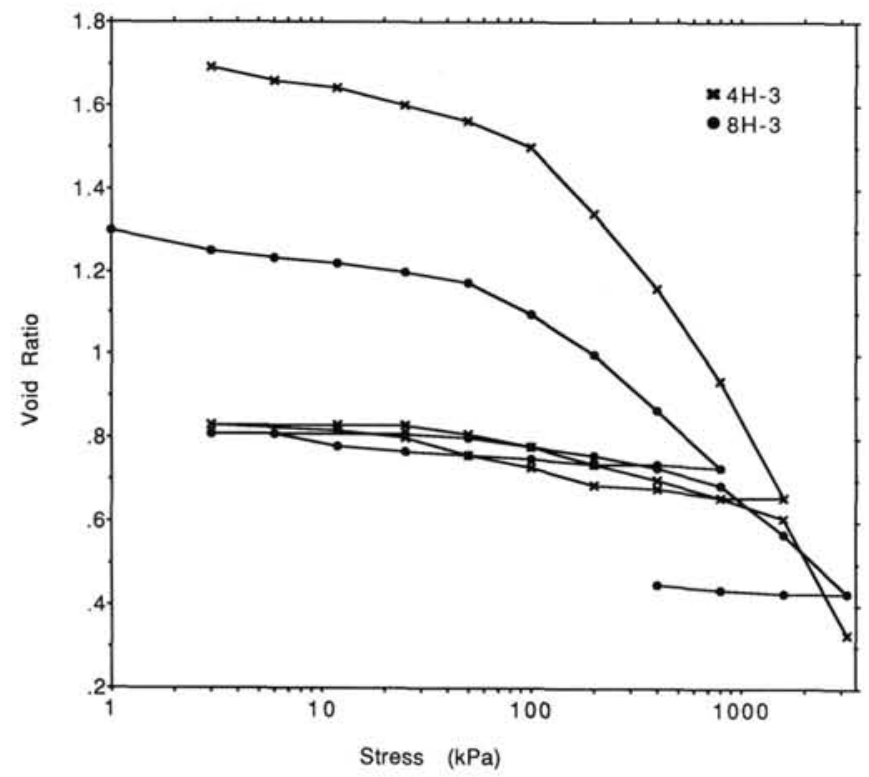

Figure 18. Curves of void ratio vs. log vertical effective stress for sediment from 26.45 and 64.83 mbsf at Hole 695A.

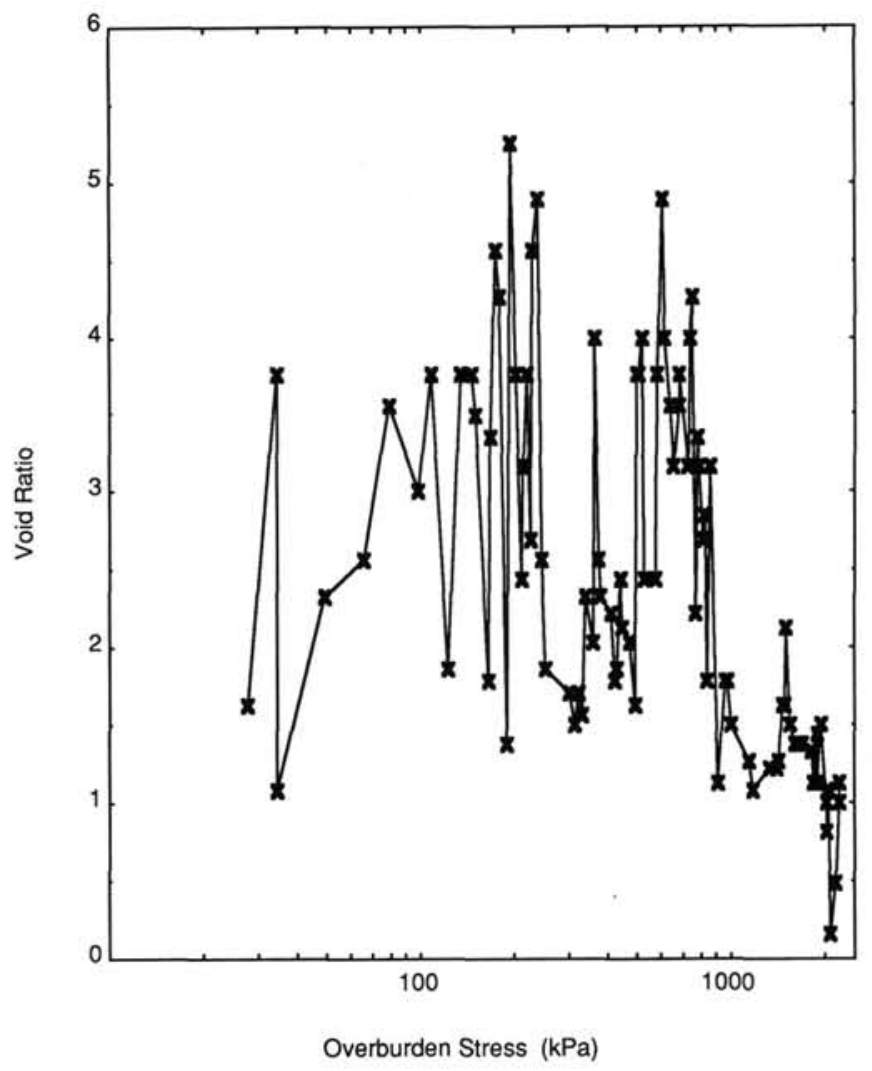

Figure 19. Field consolidation curve for Hole 695A.

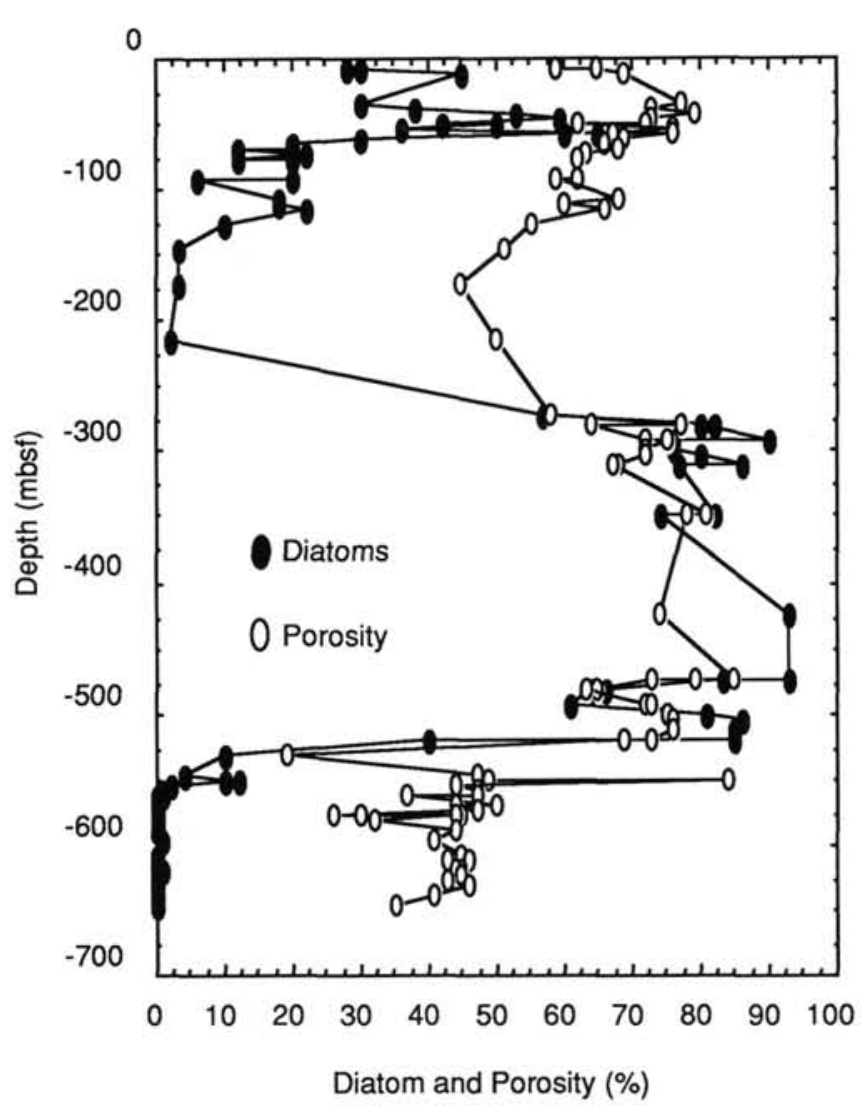

Figure 20. Profiles of porosity and percent diatoms vs. depth for Hole $696 \mathrm{~A}$. 
Figure 21 illustrates the relationship between diatom content and the ratio of shear strength to vertical effective stress at Site 696. While there is a correlation between diatom content and strength/stress ratio, the association may be more a function of porosity than of diatom content. It is interesting, however, that for the upper $225 \mathrm{~m}$ of Site 696 the strength/stress ratio follows the changes in trend for diatom content fairly well. Unfortunately shear strength was not measured much deeper than 200 mbsf, thus this relationship was not determined for the diatomaceous material found at greater depths. The results of consolidation tests on samples from 56.5 and $74.08 \mathrm{mbsf}$, are summarized in Table 1. The tests show that both samples are highly underconsolidated. The same condition is shown in Figure 21, the strength/stress ratio vs. depth profile. The measured permeability of the sediment at $74.08 \mathrm{mbsf}$ was $7.6 \times 10^{-8} \mathrm{~cm} / \mathrm{s}$. The field consolidation curve (Fig. 22) reflects the high void ratio and porosity of a diatomaceous material, particularly at the 2000-3000 kPa stress level.

It is unusual for marine sediments to have such high porosity at such great depth within a sediment section. Figure 20 shows that the porosity between 400 and 500 mbsf in the section is as high as $84.5 \%$. Much of this porosity must be ineffective, as the material does not behave as a highly permeable sediment; in fact, the material is basically impermeable.

\section{Site 697}

Site 697 is located in Jane Basin to the east of the South Orkney microcontinent. The water depth at this site is $3484 \mathrm{~m}$. The $322.9 \mathrm{~m}$ drilled section has been divided into two units (Barker, Kennett, et al., 1988). Unit I (0-293 mbsf; Pliocene to Pleistocene) contains silty and clayey mud, diatom-bearing silty and clayey mud, clay and diatom clayey mud. Unit II (293.0-322.9

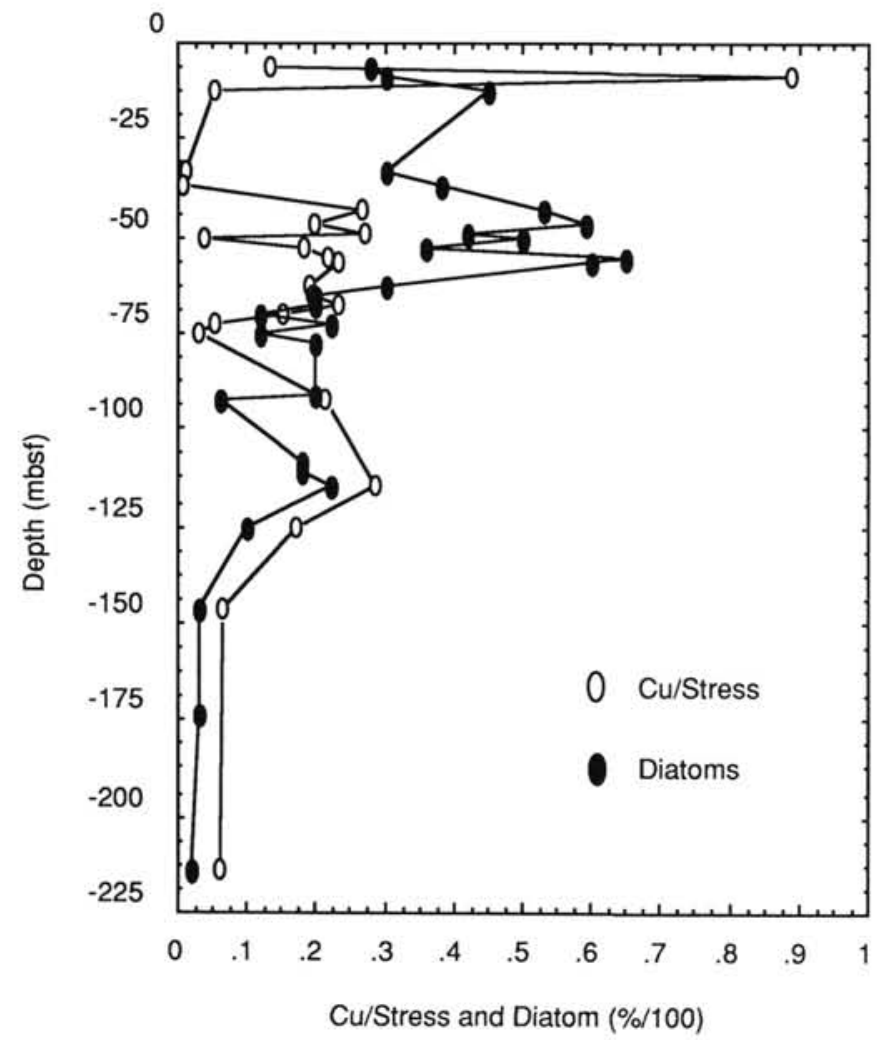

Figure 21. Ratio of undrained shear strength to vertical effective stress and decimal percent diatoms, plotted against depth for Hole 696A. Ratios between 0.2 and 0.5 are considered normally consolidated.

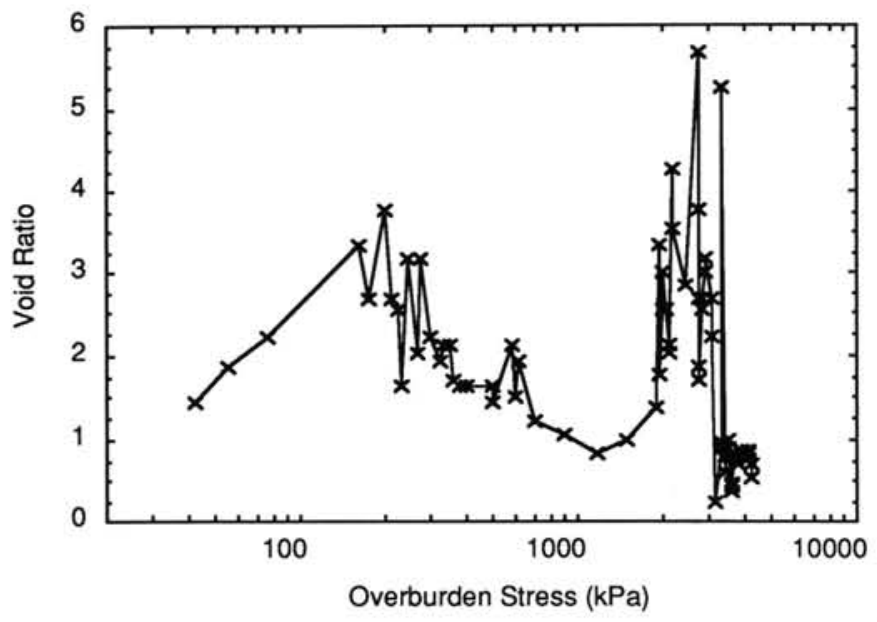

Figure 22. Field consolidation curve for Hole 696A.

mbsf; lower Pliocene) consists of silty and clayey mud, more coarse-grained than Unit I with ice-rafted detritus; diatoms are very rare.

Figure 23 illustrates the porosity and ratio of undrained shear strength to vertical stress plotted against depth for sediments at Site 697 . The porosity profile at this site is typical of a marine silty clay. The porosity of sediment below $15 \mathrm{mbsf}$ decreases with depth in a more or less steady fashion at $0.04 \% / \mathrm{m}$. The low abundance of diatomaceous material, less than $15 \%$, is reflected in the steady decrease in porosity with depth. The strength/ stress ratio illustrated in Figure 23 suggests that sediments at

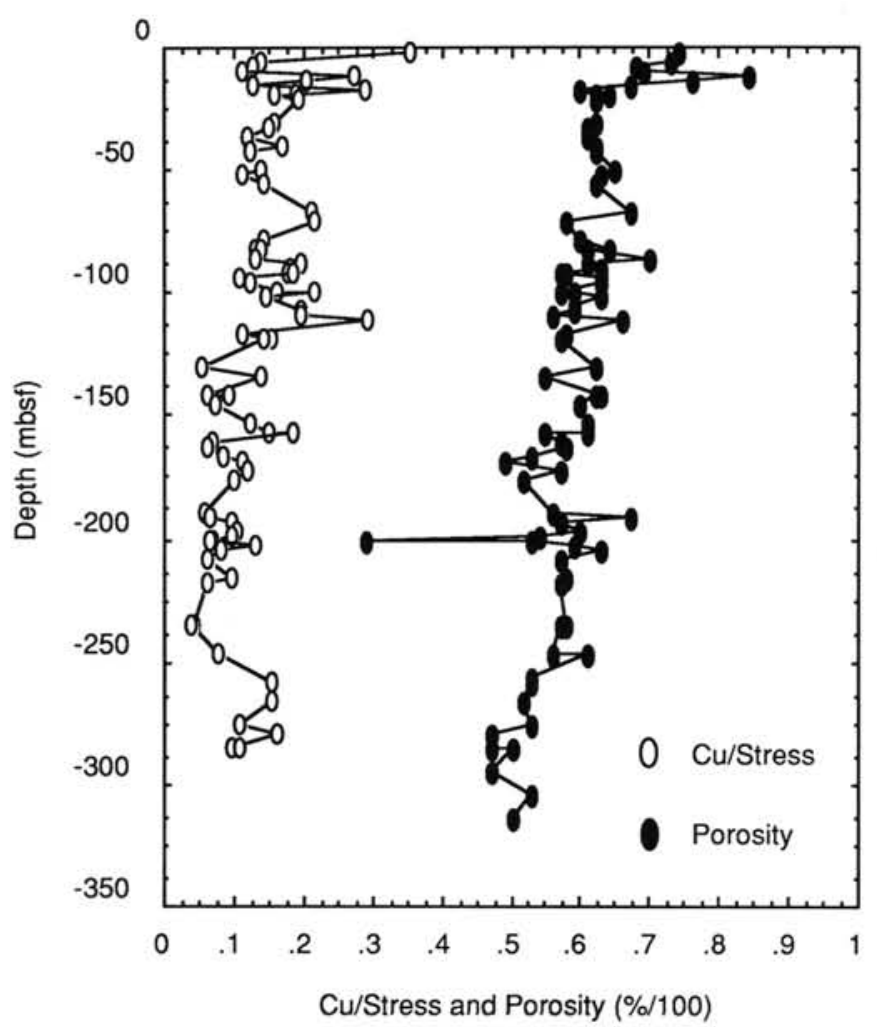

Figure 23. Ratio of undrained shear strength to vertical effective stress and decimal percent porosity for Site 697 plotted against depth. Ratios between 0.2 and 0.5 are considered normally consolidated. 
Site 697 are underconsolidated except for several samples above $15 \mathrm{mbsf}$ and between the 70 and $110 \mathrm{mbsf}$ levels. The degree of underconsolidation increases with depth up to $240 \mathrm{mbsf}$, at which point the sediments become less underconsolidated.

Figure 24 illustrates the curves of void ratio vs. log vertical stress generated from consolidation test data. The silty clays of Site 697 are highly compressible. It is interesting to note that the final void ratio at the $3200 \mathrm{kPa}$ stress level is similar regardless of the initial void ratio of the sediments. A summary of the consolidation test results is given in Table 1. The four samples tested were underconsolidated to highly underconsolidated at greater depth. The underconsolidation of these sediments reflects their permeability. The sediments in the deeper portions of the section had permeabilities that ranged from $9 \times 10^{-9}$ to $5 \times 10^{-10} \mathrm{~cm} / \mathrm{s}$.

The field consolidation curve for Site 697 is shown in Figure 25 . The fairly flat slope of the curve and the closer grouping of the data, compared with curves from other sites with large variations in diatom content, is typical of marine clay investigated from other areas of the world.

\section{DISCUSSION AND CONCLUSIONS}

The reduction in porosity of the siliciclastic, calcareous, and diatomaceous sediments of the Weddell Sea, Maud Rise, and South Orkney microcontinental margin is primarily governed by lithology and by vertical stresses created by overburden. Diatom-rich sediments retain the highest porosities with depth below the seafloor of any sediment and diatom content above $15 \%$ influences the porosity of both calcareous and siliciclastic sediments. The correlation coefficient relating the abundance of diatoms and the porosity of a given sediment ranks at 0.81 .

Surficial diatom-rich sediments, regardless of their location, are overconsolidated in all cases. This is attributed to the strong microfabric formed by diatoms, the high porosity, and high permeability of the sediment. The high permeability allows rapid drainage. Cementation of the silica tests of the diatomaceous sediment has not been identified at any site.

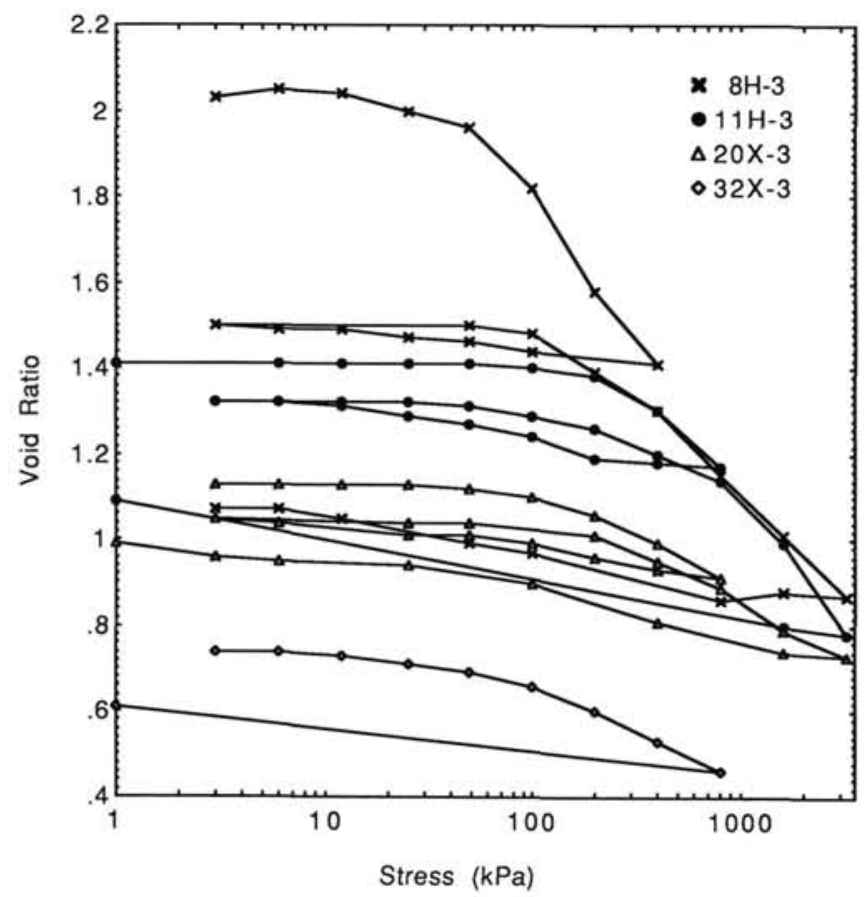

Figure 24. Curves of void ratio vs. $\log$ vertical effective stress for sediments from 90.1, 118.72, 200.6, and $316.66 \mathrm{mbsf}$ at Hole 697B.

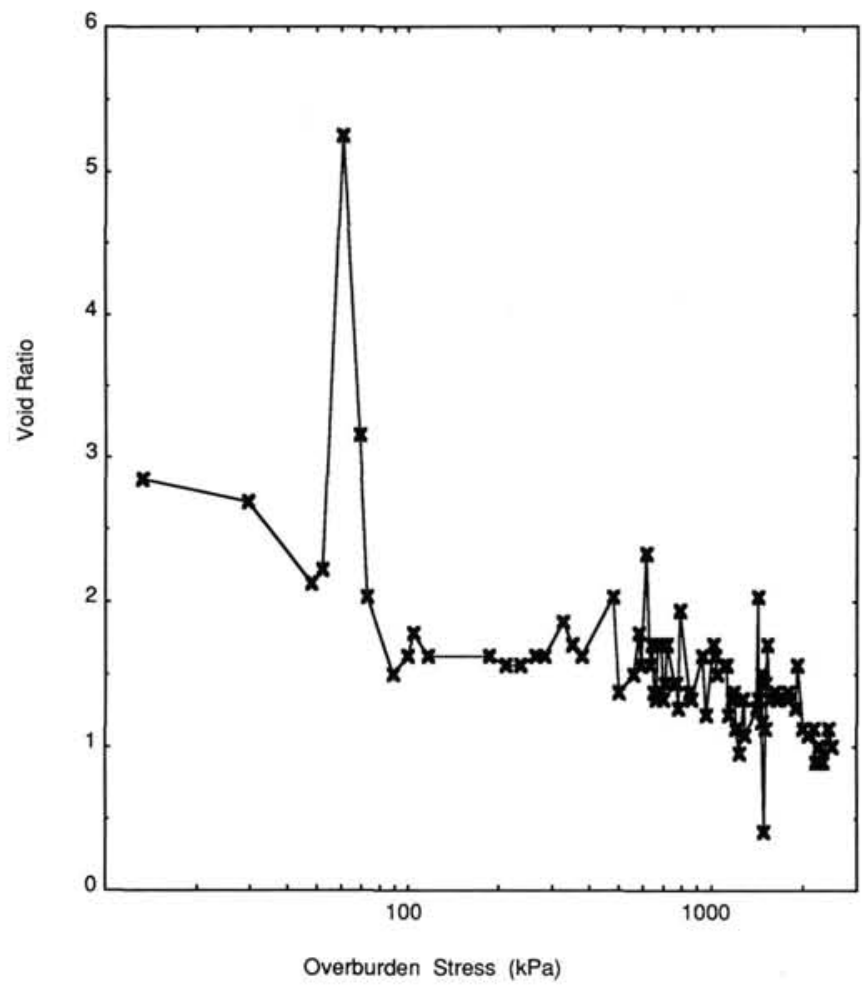

Figure 25. Field consolidation curve for Hole 697B.

Figure 26 is the $\log$ of vertical stress at Sites 693, 695, 696, and 697 vs. depth. It shows the overburden pressure present at any depth up to $400 \mathrm{mbsf}$ for each site. Superimposed on the graph are measured preconsolidation stress values determined from ten consolidation tests. Nine of the ten values of preconsolidation stress are below the vertical stress (overburden stress) curves. This indicates that the sediments are underconsolidated. They have not adjusted to the stress imposed upon them and may have high excess pore water pressures. The only sample that had a preconsolidation stress in excess of the overburden stress was one with a diatom content of $45 \%$ (see Table 1). The measured permeability of these sediments ranges from $5.8 \times 10^{-4}$ to $1 \times 10^{-10} \mathrm{~cm} / \mathrm{s}$. The underconsolidated nature of these sediments is in part attributed to their low permeability.

Figure 27 illustrates the overburden stress vs. depth for the sediments of Site 689 and 690 . The three values of preconsolidation stress determined by consolidation testing, that are positioned above the overburden stress levels in Figure 27, are from diatomaceous sediments. The remaining four values lie close to the overburden stress profiles indicating that they are normally consolidated or slightly underconsolidated. These sediments are mainly calcareous and have fairly low permeabilities. The degree of consolidation as measured by consolidation tests is similar (in three quarters of the cases) to that determined by the relationship between undrained shear strength and vertical effective stress (Table 2).

The sediments sampled on Leg 113 display a degree of underconsolidation similar to those determined in a number of different locations throughout the world's oceans. The very low permeability of Weddell Sea sediments appears to be in part the reason for this underconsolidation, as in other areas (Bryant et al., 1981, 1987)

\section{ACKNOWLEDGMENTS}

Partial support for this research was provided by USSAC of the Joint Oceanographic Institutions. Thanks are extended to 


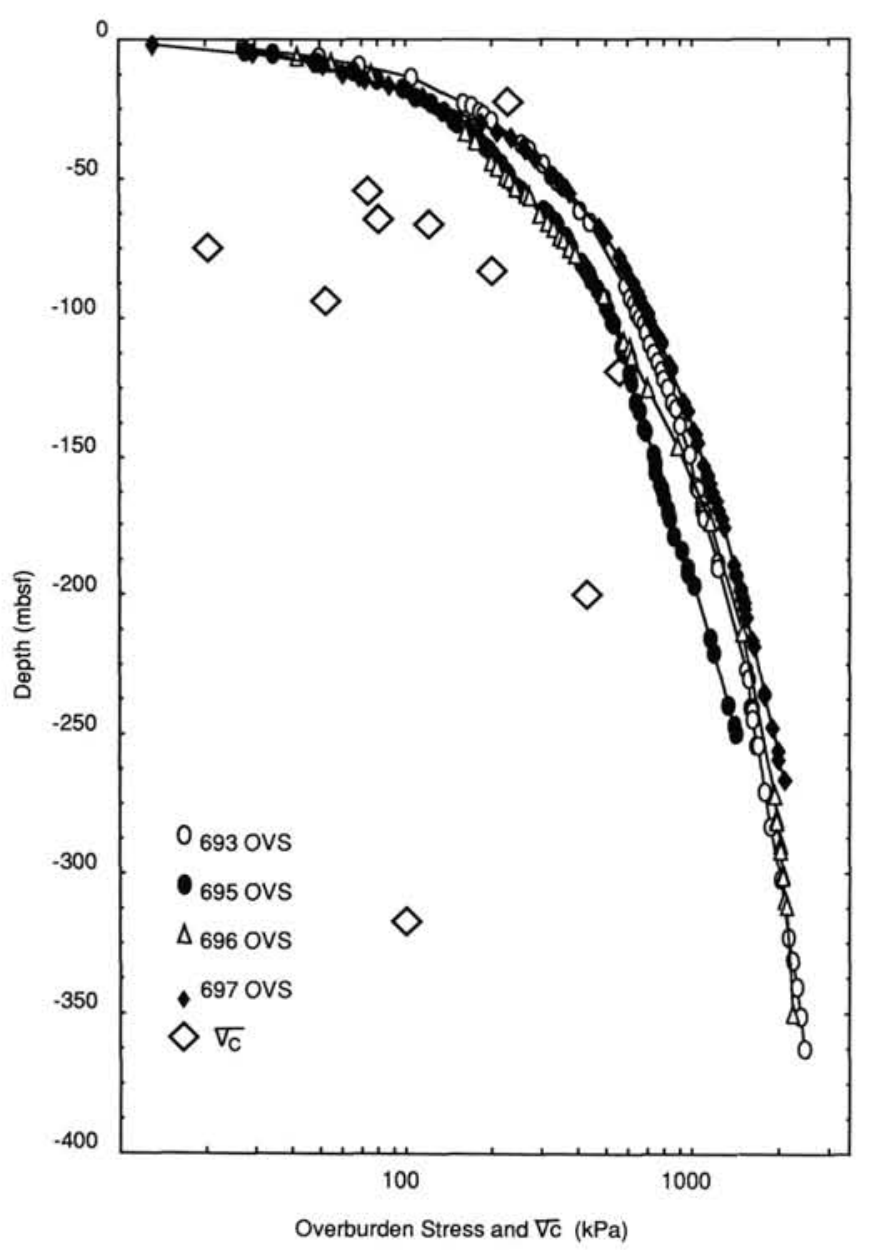

Figure 26. Log of vertical effective stress vs. depth for Holes 693A, $695 \mathrm{~A}, 696 \mathrm{~A}$, and 697B and preconsolidation stress values from 10 consolidation tests.

Table 2. Results of consolidation tests.

\begin{tabular}{|c|c|c|c|c|c|}
\hline $\begin{array}{l}\text { Hole, core, } \\
\text { section }\end{array}$ & $\mathrm{S}_{\mathrm{u}} / \sigma_{\mathrm{o}}{ }^{\prime}$ & $\begin{array}{l}\text { Consolidation } \\
\text { characteristics }^{\mathrm{a}}\end{array}$ & $\left(\sigma_{0}\right)$ & $\left(\sigma_{c 4}\right)$ & $\begin{array}{l}\text { Consolidation } \\
\text { characteristics }^{\mathrm{a}}\end{array}$ \\
\hline $689 \mathrm{C}-3 \mathrm{H}-3$ & 1.40 & $\mathrm{HOC}$ & 7.01 & 8.77 & HOC \\
\hline $689 \mathrm{D}-2 \mathrm{H}-2$ & 0.60 & OC & 4.50 & 3.21 & OC \\
\hline $689 \mathrm{D}-5 \mathrm{H}-2$ & 0.32 & $\mathrm{NC}$ & 1.06 & 1.13 & NC \\
\hline 689D-11H-1 & 0.03 & HUC & 0.73 & 0.96 & UC \\
\hline $690 \mathrm{C}-2 \mathrm{H}-1$ & 0.90 & $\mathrm{HOC}$ & 8.57 & 8.09 & $\mathrm{HOC}$ \\
\hline $690 \mathrm{C}-5 \mathrm{H}-1$ & 0.23 & $\mathrm{NC}$ & 0.44 & 0.56 & UC \\
\hline $690 \mathrm{C}-8 \mathrm{H}-1$ & 0.12 & UC & 0.76 & 1.11 & UC-NC \\
\hline $693 \mathrm{~A}-8 \mathrm{R}-4$ & 0.05 & HUC & 0.16 & 0.18 & HUC \\
\hline $695 \mathrm{~A}-4 \mathrm{H}-3$ & 0.30 & NC & 2.19 & 2.19 & OC \\
\hline $695 \mathrm{~A}-8 \mathrm{H}-3$ & 0.14 & UC & 0.32 & 0.30 & UC \\
\hline $695 \mathrm{~A}-10 \mathrm{H}-3$ & 0.14 & UC & 0.53 & 0.45 & UC \\
\hline $696 \mathrm{~A}-7 \mathrm{H}-4$ & 0.09 & HUC & 0.01 & 0.07 & HUC \\
\hline 696A-9H-3 & 0.16 & UC & 0.03 & 0.07 & HUC \\
\hline $697 \mathrm{~B}-8 \mathrm{H}-3$ & 0.18 & UC & 0.09 & 0.08 & HUC \\
\hline $697 \mathrm{~B}-11 \mathrm{H}-3$ & 0.15 & UC & 0.56 & 0.70 & UC \\
\hline 697B-20X-3 & 0.09 & HUC & 0.18 & 0.28 & HUC \\
\hline $697 \mathrm{~B}-32 \mathrm{X}-3$ & 0.10 & HUC & 0.03 & 0.04 & HUC \\
\hline
\end{tabular}

${ }^{\mathrm{a}} \mathrm{HOC}=$ Highly overconsolidated OC $=$ Overconsolidated NC $=$ Normally consolidated; UC $=$ Underconsolidated; HUC $=$ Highly underconsolidated.

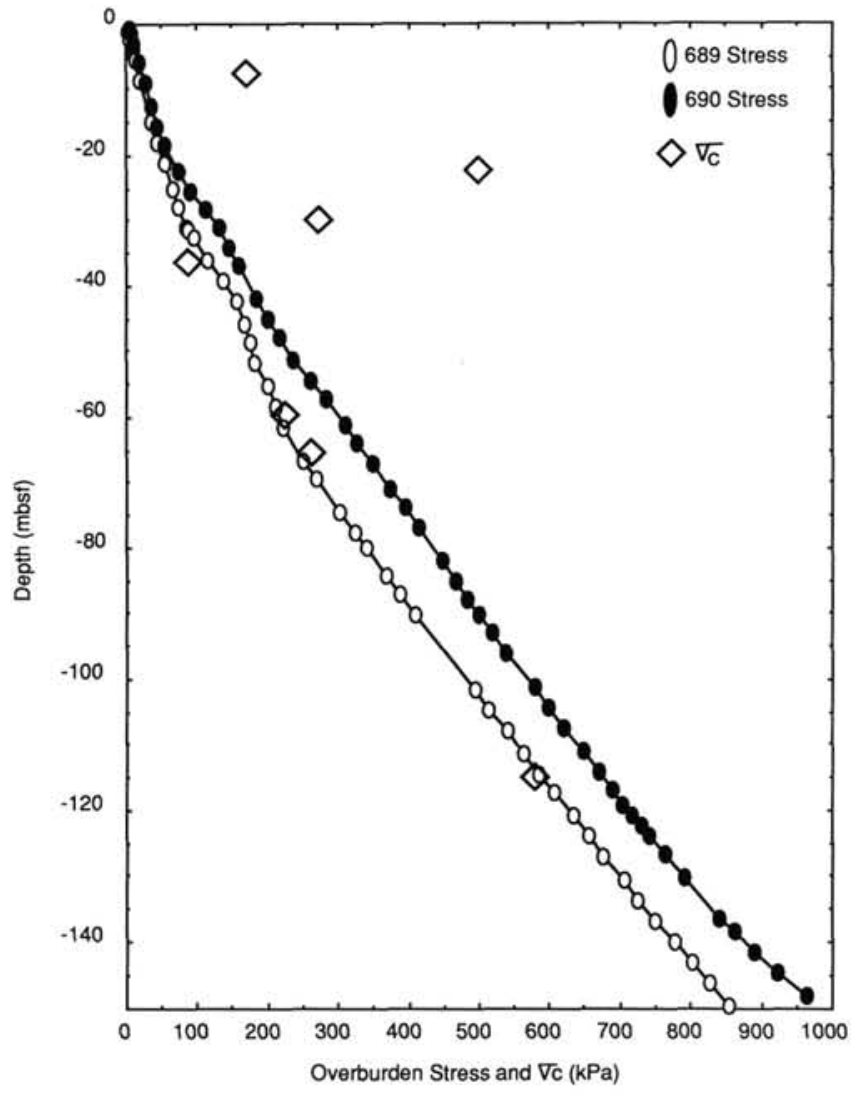

Figure 27. Vertical effective stress vs. depth for Holes 689D and 690C and preconsolidation stress values from consolidation tests of Holes 689D and 690C sediment samples.

those unknown reviewers whose efforts made this paper much better than the original draft.

\section{REFERENCES}

Barker, P. F., Kennett, J. P., et al., 1988. Weddell Sea paleoceanography: preliminary results of ODP Leg 113. Palaeogeogr., Palaeoclimatol., Palaeocol., 67:75-102.

Bishop, A. W., Webb, D. L., and Lewis, P. I., 1965. Undisturbed samples of London Clay from the Ashford Common Shaft: strength-effective stress relationship. Geotechnique, 15:1-31.

Bryant, W. R., Bennett, R., and Katherman, C., 1981. Shear strength, consolidation, porosity, and permeability of oceanic sediments. In Emiliani, C. (Ed.), The Sea, 7: The Oceanic lithosphere: New York (John Wiley and Sons), 1555-1616.

Bryant, W., Wetzel, A., Taylor, E., and Sweet, W., 1986. Consolidation characteristics and permeability of Mississippi Fan sediments. In Bouma, A. H., Coleman, J. M., Meyer, A. W., et al., Init. Repts. DSDP, 96: Washington (U.S. Govt. Printing Office), 797-809.

Burmister, D. M., 1951. The application of controlled test methods in consolidation testing. Consolidation Testing of Soils, Am. Soc. Testing Materials, 126:83-91.

Casagrande, A., 1936. The determination of the preconsolidation load and its practical significance. Proc. First Int. Conf. Soil Mech. Found. Eng., 3:60-64.

Cooling, L. F., and Skempton, A. W., 1942. A laboratory study of London clay. J. Inst. Civil Eng. London. 17:251-256.

De Ruiter, J., and Richards, A. F., 1983. Marine geotechnical investigations, a mature technology. In Wright, S. G. (Ed), Geotechnical Practice in Offshore Engineering. Am. Soc. Civil Eng., 1-24.

Dunlap, W. A., and Bryant, W. R., 1978. Pore pressure measurements in underconsolidated sediments. Proc. 11th OTC, Houston, Paper 4840:541-548.

Gray, M. R., McAffe, R., Jr., and Wolf, C. L., 1972. Glossary of Geology: Washington, D.C. (Am. Geol. Inst.). 
Lambe, T. W., 1951. Soil Testing for Engineers: New York (John Wiley and Sons).

Lambe, T. W., and Whitman, R. V., 1969. Soil Mechanics: New York (John Wiley and Sons).

Lowe, J., III, 1974. New concepts in consolidation and settlement analysis. J. Geotech. Eng. Div. Am. Soc. Civil. Eng., 100(GT6), 574612.

Marine Geotechnical Consortium, 1985. Geotechnical properties of Northwest Pacific pelagic clays, Deep Sea Drilling Project Leg 86, Hole 576A. In Heath, G. R., Burckle, L. H., et al., Init. Repts. DSDP, 86: Washington (U.S. Govt. Printing Office), 723-758.

Pittenger, A., Taylor, E., and Bryant, W., 1989. The influence of biogenic silica on the geotechnical stratigraphy of the Vøring Plateau:. Norwegian Sea. In Eldholm, O., Theide, J., Taylor, E., et al., Proc. ODP, Sci. Results., 104: College Station, TX (Ocean Drilling Program), 923-940.
Schmertmann, J. H., 1955. The undisturbed consolidation behavior of clay. Trans. Amer. Soc. Civil Eng., 120:1201-1227.

Skempton, A. W., 1970. The consolidation of clays by gravitational compaction. Quar. J. Geol. Soc. London, 125:373-411.

Terzaghi, K., 1943. Theoretical Soil Mechanics: New York (John Wiley and Sons).

Trimm, B. A., 1989. Analysis of preconsolidation pressure methods for fine-grained marine sediments. [M. S. thesis] Texas A\&M Univ., College Station, Texas.

Date of initial receipt: 1 March 1989

Date of acceptance: 16 October 1989

Ms 113B-173 